\title{
8. NEOGENE SAND LAYERS OFF NORTHWEST AFRICA: COMPOSITION AND SOURCE ENVIRONMENT
}

\author{
Michael Sarnthein, Geologisch-Palaeontologisches Institut der Universitaet Kiel, West Germany
}

\begin{abstract}
Neogene sand layers were recovered during DSDP Legs 14 and 41 in seven holes at the West African continental margin, between $12^{\circ}$ and $35^{\circ} \mathrm{N}$. Based on their sedimentary structures, grain sizes, and the composition of their coarse fractions, three major genetic groups of sand layers are distinguished: contourites, turbidites originating from fluvial deltas, and turbidites formed by eolian dune sands, both in proximal and distal facies. The source environments are characterized by compositional features, which are independent of transport sorting, such as the abundance of feldspar, of stained and frosted quartz, or the composition of reworked faunas. Eolian-sand turbidites are the only layers with noticeable open porosity. They occupy a time-transgressive zone which follows a northward platetectonic shift from the Pleistocene to the early Miocene of the area between $14^{\circ}-20^{\circ} \mathrm{N}$ by 6 to 7 degrees of latitude. During the Pleistocene, this zone is marked as the synglacial position of Sahara dunes advancing towards the shore line at the shelf edge and generating turbidity currents at the slope. Fluvial-sand turbidites occur further to the south and north. The turbidites at Sites 370 and 135 are additionally influenced by the rising Atlas Mountains.

Turbidites and contourites both appear concentrated in a few stratigraphic horizons: at 23 to $20, \sim 13$, and 3 to 2 m.y.B.P. The paleoenvironment of these horizons can be characterized by a low sea level (indicated by the formation of eolian-sand turbidites itself and by abundant erosion of glauconite on emerged shelf plains), by vigorous off-shore Trade Winds (moving dunes towards the shore and forming dust beds on the slope), by strong coastal upwelling (dominance of fish remains and siliceous fossils at the supposed center of Trade Winds influence), by temperate temperatures in coastal waters (skeletal sands of "Foramol" group), and by increased bottom-current activity (contourites). In conclusion, these conditions resemble Pleistocene glacial events and agree well with evidence from other parts of the oceans.

An early phase of Cape Verde volcanism shows up with pumice grains in the lower NN 18 Zone.
\end{abstract}

\section{INTRODUCTION}

The composition of turbidites is determined by the nature of the source environment, erosion during transport and by sorting processes. This paper provides a summary of information on the composition of Neogene and Oligocene sandy layers off northwest Africa, most of which are assumed to be deposited by turbidity currents and related grain flows. ${ }^{1}$ The layers were studied in 21 cores which were recovered at seven sites during Legs 14 and 41 of the Deep Sea Drilling Project.

This study follows previous ones (Sarnthein and Walger, 1974; Sarnthein and Diester-Haass, 1976) on the eolian-sand transport off of the western Sahara, and extends models of Holocene and Pleistocene climate

\footnotetext{
'The term "turbidite" is used in a summarizing sense.
}

belts into the Tertiary. The turbidites are used as a unique storage of information on: (1) periods of low sea-stands with a strand line close to the shelf edge, (2) ancient desert environments with an off-shore wind regime, and (3) the ancient position of arid and humid climate belts, which are short lived and shift rapidly leaving behind only minor and difficult-to-date traces on the continental platforms.

The areal and stratigraphic distribution of cores is shown on Figures 1 and 2, respectively. The upper Tertiary was only spot cored because the primary objectives of Sites 367 and 370 were to encounter deep horizons. Core recovery was much better at Site 368, but sandy layers rarely occur there. Table 1 summarizes the length of stratigraphic record represented by the cores (Berger and von Rad, 1972), and the distribution of core lengths at Sites 367,368 , and 370 . In regard to this table, it must be stated that the stratigraphic and paleoenvironmental interpretations of this report 


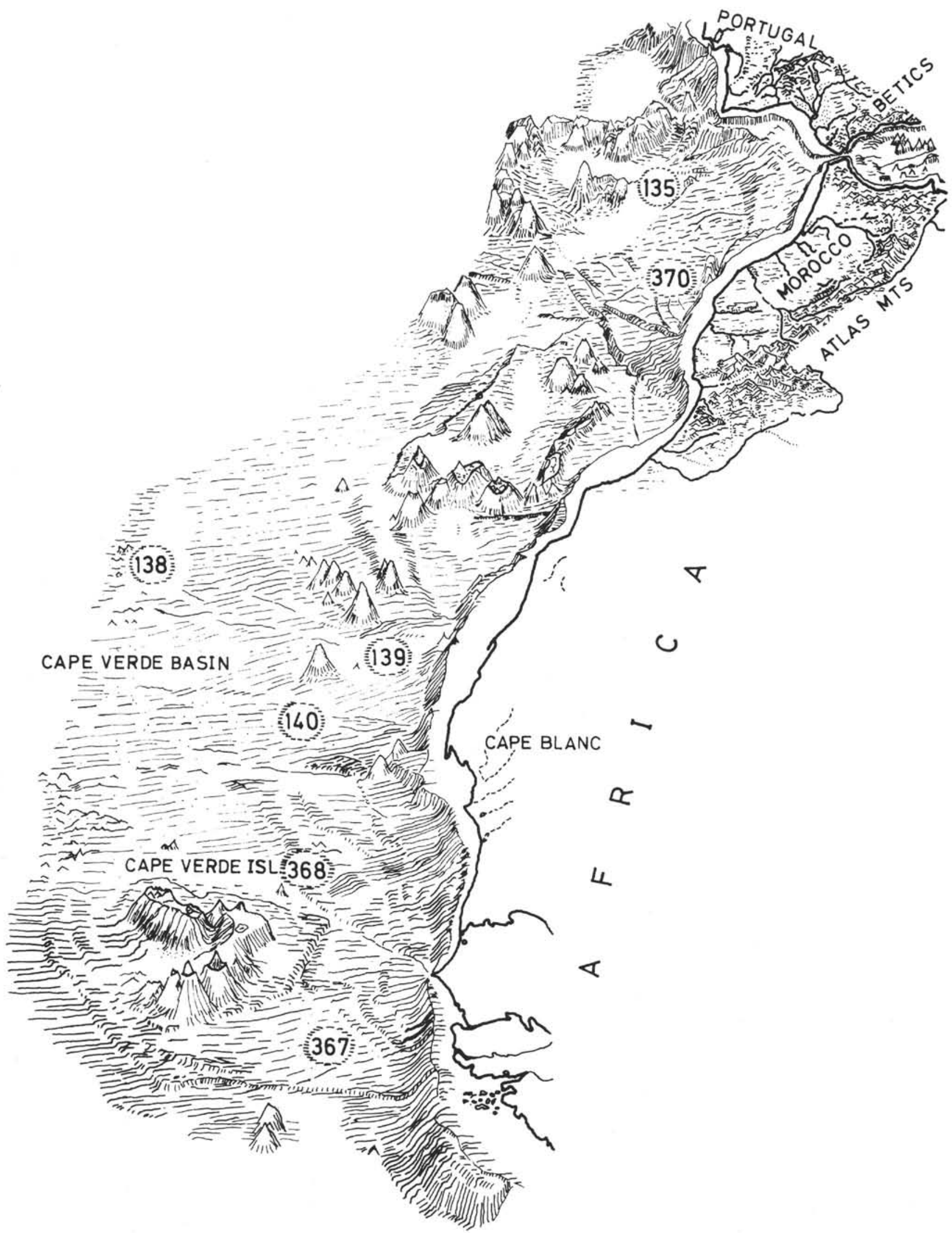

Figure 1. Physiographic setting of Sites 135, 138 to 140 (Leg 14), 367, 368, and 370 (Leg 41). Note that Site 138 is the most distal of sites and is in line with a channel coming from Site 139. Site 368 is on the Cape Verde Rise. Modified base map from Berger and von Rad (1972). 

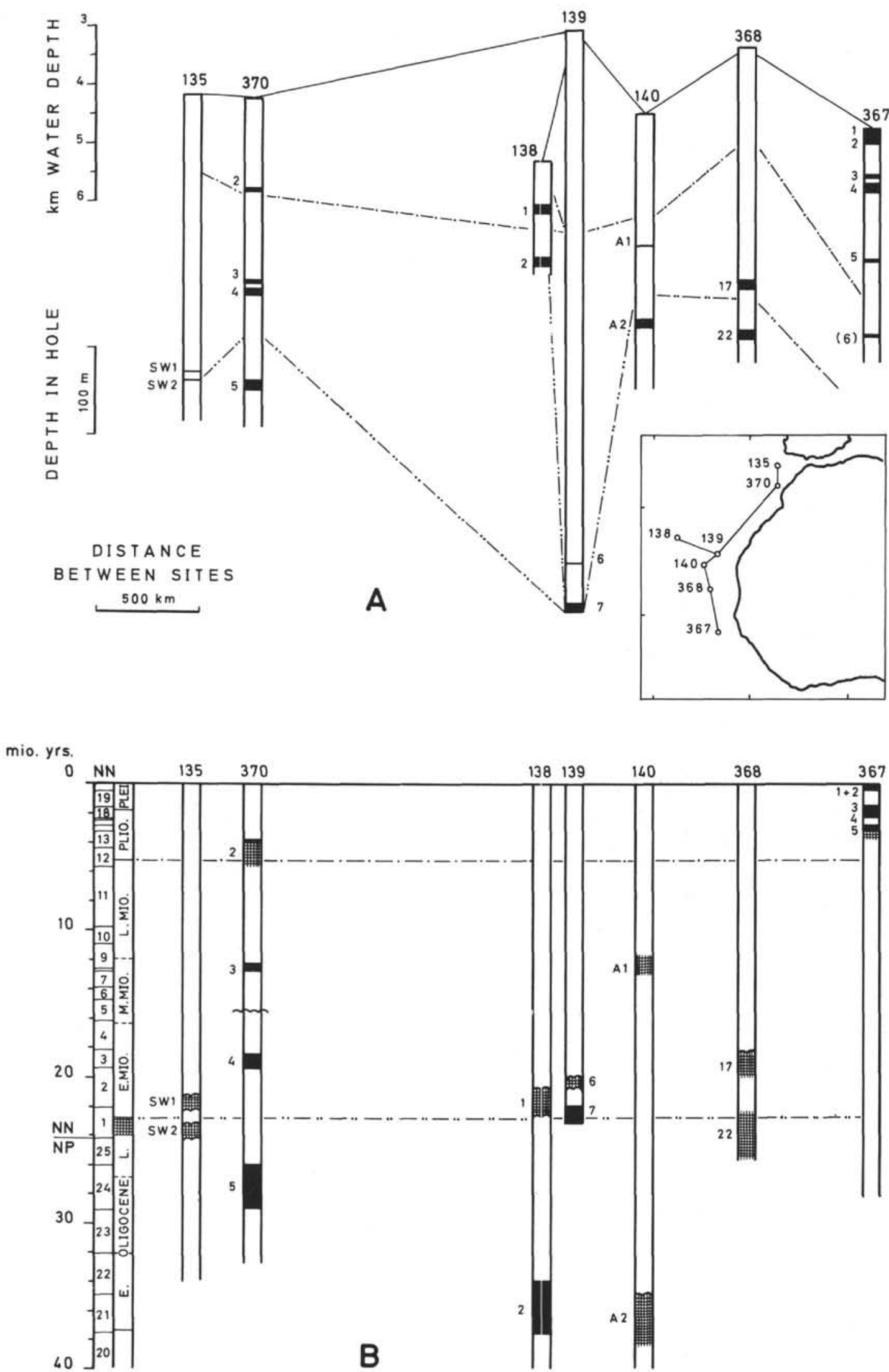

Figure 2. Position (A) and ages (B) of cores containing sand layers. Blank core boxes refer to uncertainties in dating. 
TABLE 1

Sample Representation of Oligocene to Pleistocene Cores

\begin{tabular}{ccc}
\hline $\begin{array}{c}\text { Percentage of Cores } \\
\text { in Length Classes } \\
(\mathrm{m})\end{array}$ & \multicolumn{2}{c}{$\begin{array}{c}\text { Represented Length of Stratigraphic } \\
\text { Record }(\mathrm{m})\end{array}$} \\
Sites 367, 368, 370 & $\begin{array}{c}\text { Sites } 367 \text { and } 370 \\
\text { Cores (\%) }\end{array}$ & $\begin{array}{c}\text { Site } 368 \\
\text { Cores }(\%)\end{array}$ \\
\hline $47 \%>8.0$ & $8.5 \%<10$ & $64.0 \%<10$ \\
$15 \% 4.5-6.0$ & $16.5 \% 21-30$ & $13.5 \% 11-20$ \\
$23 \% 2.5-4.0$ & $8.5 \% 31-40$ & $9.0 \% 21-30$ \\
$15 \% 0-2.0$ & $16.5 \% 41-50$ & $13.5 \% 31-40$ \\
& $25.0 \% 51-60$ & \\
& $8.5 \% 81-90$ & \\
& $16.5 \% 101-110$ & \\
$100 \%$ (34 cores) & $100.0 \%(12$ cores) & $100.0(22$ cores) \\
\hline
\end{tabular}

generally suffer from a paucity of data. Additionally, the interpretations are weakened because turbidites display insights only into an ephemeral, if not incidental set of environmental conditions.

\section{DISTRIBUTION PATTERN OF SANDY LAYERS}

\section{General}

Site 138 lies most distant from the present shelf edge $(1000 \mathrm{~km})$, whereas Sites 139,367 , and 370 lie closest to the shelf edge $(280,250$, and $120 \mathrm{~km}$ distance, respectively). The seven sites cover a wide climatic range between the humid northern tropical belt in the south (Site $367: 12^{\circ} 30^{\prime} \mathrm{N}$ ) and the humid Mediterranean belt in the north (Site $135: 35^{\circ} 10^{\prime} \mathrm{N}$, Site $370: 32^{\circ} 50^{\prime} \mathrm{N}$ ). This distribution was shifted some $6^{\circ}$ to $7^{\circ}$ of latitude southward in the early Miocene, according to the reconstructions of plate motions (Francheteau, 1970; Berger and von Rad, 1972).

Each sandy layer which occurs in Oligocene to Holocene cores was sampled and catalogued for thickness, internal fabrics, character of its boundaries, its relations to neighboring facies, and artificial disturbances.

Unless otherwise stated, the age classification of Leg 41 cores was determined by the shipboard paleontologists (P. Cepek, D. Johnson, V. Krasheninnikov, and $\mathrm{U}$. Pflaumann) by means of coccolithophorids, radiolarians, and foraminifera. The ages of cores from Leg 14 are from Hayes, Pimm, et al., 1972. Absolute ages were correlated to the biostratigraphy following Berggren and van Couvering (1974) and Ryan et al. (1974).

\section{Site 367}

Site 367 lies southwest of Cape Verde at the eastern boundary of the Senegal Abyssal plain, off the Saloum River mouth, beyond the present influence of the Cayar Canyon fan. Two categories of sandy layers occur in Cores I through 5.

Dark and fine quartzose sandy beds appear in Cores 1 and 2 (upper Pleistocene). The beds are thin (Figure 3 ) and frequently dragged into lenticular or wedge forms by coring disturbance. The sandy layers have sharp contacts with the adjacent nanno marl and dark gray silty clay and show no gradation or internal fabrics. This lack of structures may also be the result of drilling disturbance.
Cores 3, 4, and 5 (upper Pliocene) contain mediumsized, reddish-yellow quartzose sand beds which are massive (Figure 3; up to $>1 \mathrm{~m}$ ) and occur at frequent intervals (12 layers in $12.5 \mathrm{~m}$ core length). Drilling disturbance is common and results in a dragging of the sand beds into wedges and lenses, and in the intrusion of flakes from the overlying muds. The beds show no lamination and almost no gradation regardless of thickness. Heavy mineral layers ( 1 to $2 \mathrm{~cm}$ thick) characterize some of the beds at their base. The upper contacts are as sharp as the lower ones, but some of the lower contacts are wavy and indicate erosional processes may have preceded deposition.

\section{Site 368}

Site 368 was drilled on top of the Cape Verde Rise. Sand layers occur as tiny and sharply defined lenses and interbeds of fine white sand in the early Miocene of Cores 17 and 18 . The layer thickness ranges from 0.1 to $1.0 \mathrm{~cm}$. No internal structures were observed. Core 22 (middle Eocene to early Miocene) contains a sequence of coarse-sediment beds a few $\mathrm{cm}$ thick which may be of volcanic origin. They show an upward gradation into greenish claystones. The sediments younger than early Miocene lack any coarse-sediment layer.

\section{Site 370}

Site 370 lies in a 650 -meter-thick submarine fan off the Moroccan continental margin. Fan deposition has been active since at least the Paleocene. Hemipelagic sediments between Oligocene (Core 5) and Pliocene (Core 2) contain regular silt and sand layers and indicate a strong terrigenous influence persisted during that time. The sand beds occur in narrow intervals ( 59 layers in 18.5-m core length), are generally thin (Figure 3 ), and distinctly graded. Lamination and convolute bedding are common. Most of the lower contacts show the effects of erosion on reddish-white or greenish-gray marl. The lower part of Core 4 shows a striking example of slumping and graded-bed structures. The sands are predominantly dark-green. Drilling disturbance is rare and slight.

It is interesting to note that thin layers and nodules of porcellanites are frequently associated with the top of graded layers, the youngest ones occurring in the upper part of Core 3 (middle Miocene). Lithification generally increases from 200 meters depth (Core 3) downward, a factor which has significantly biased the grain-size analyses because of the formation of stiff mud and silt lumps. A major hiatus might best explain the distinct age difference between the two successive cores (Site 370, Cores 3 and 4).

\section{Sites 135 and 138, 139, 140 (Leg 14)}

The DSDP Leg 14 sites are discussed by Berger and von Rad (1972). Neogene to Oligocene quartzose sand layers exist in Cores 135-SW1 and SW2, 138-1 and 2, 139-6 and 7, and 140A-1 and 2. Apart from their lesser degree of staining, most sand beds from Leg 14 basically correspond to those of Cores $367-3$ to 5 with their lack of gradation regardless of thickness, their coarse, loose appearance, and their massiveness (Figure $3)$. Noticeable signs of lithification were observed only in Core 139-6. 


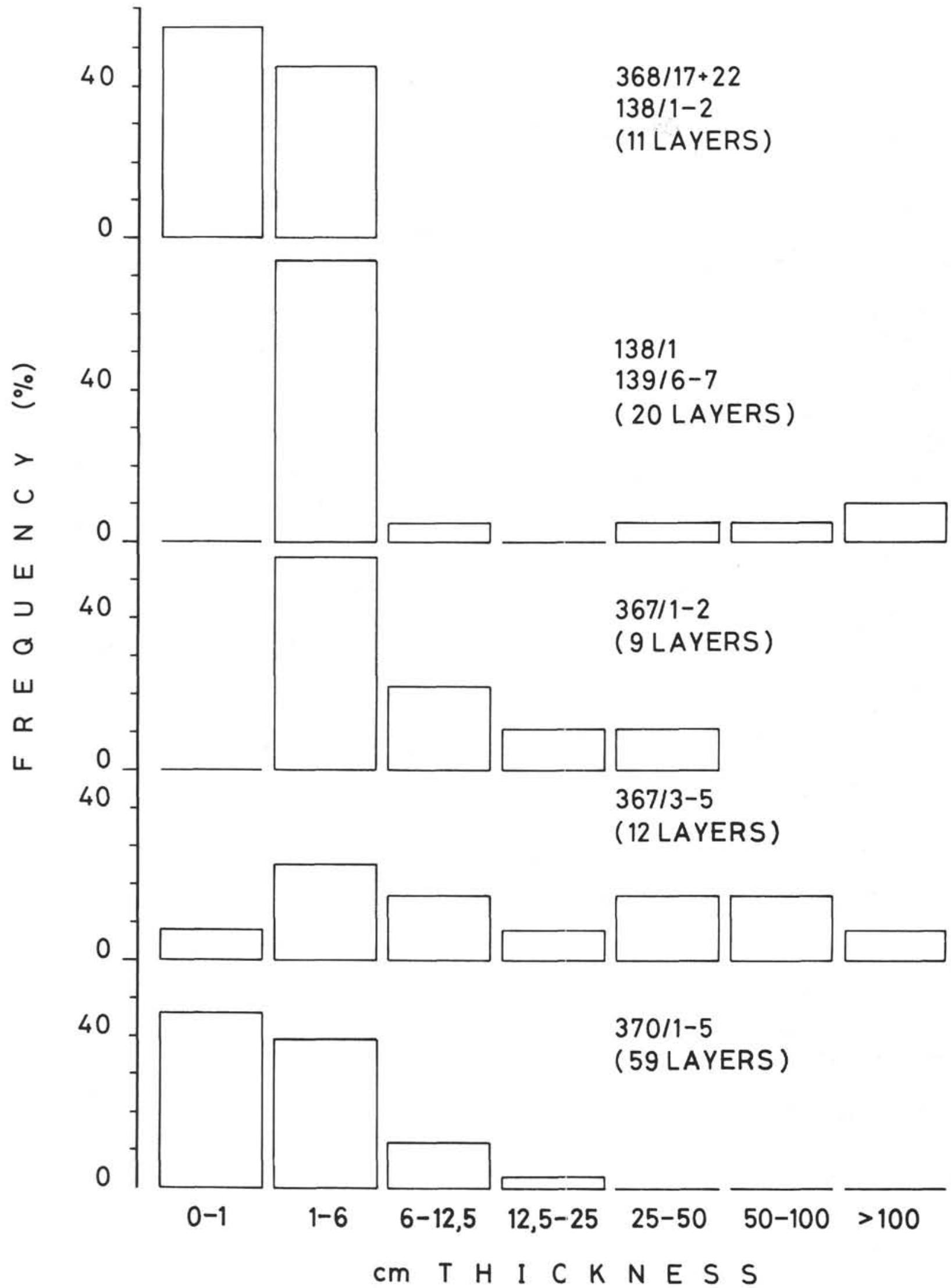

Figure 3. Frequency distribution of sand-layer thickness. 


\section{DISTRIBUTION OF GRAIN SIZES AND SAND COMPONENTS}

\section{Methods}

Samples for coarse-fraction analysis were taken from the base, the top, and the middle of thick sand layers. Thin layers were sampled only close to their base. The volume of the samples was 5 to $10 \mathrm{cc}$. The samples were wet sieved using 44 and $63 \mu \mathrm{m}$ sieves; the fine fraction was collected quantitatively and dried at $60^{\circ} \mathrm{C}$. Dry weights of the fine and coarse silt and the sand fractions $(>63 \mu \mathrm{m})$ were determined. The sand fraction was dry sieved into subfractions of -1 to 0,0 to 1,1 to 2,2 to 3 , and 3 to 4 Phi grade. The percentage proportions of the subfractions were evaluated for a median grain-size value of sand.

Two sources of bias must be kept in mind when interpreting the grain-size data: (a) It was frequently impossible to completely separate clean samples of thin sand lenses from the surrounding muds, thereby generating an artificial amount of fine fraction. (b) Increased diagenesis hindered the sieving of stiff muddy sands into true grain-size fractions, even after strong treatment by peroxide. On the other hand, intensive treatment destroyed debris of brittle pelagic mud contained as natural particles in the sand layers.

Counts of about 300 to 400 representative grains per sand subfraction were made for component analysis using a stereomicroscope with incident light (magnification up to $80 \times$ ). The grain number is sufficient in order to obtain a gross picture of the component distribution (details in Sarnthein, 1971). Quantitative component analysis was applied to all sand subfractions in samples from Sites 135, 138, 139, and 140A. Samples from Leg 41 sites were counted using only two or three dominant "key" subfractions. The other (mainly the finest) sand subfractions were examined only for the abundance of some key components (e.g., mica and stained quartz).

Thirty to 50 components were distinguished in total (Table 2), but the diversity of particles within one sample fraction was usually rather small. The difficult separation of quartz and feldspar under incident light was confined to subfractions $>250 \mu \mathrm{m}$ (rarely $>125$ $\mu \mathrm{m})$ and was confirmed by spot-check counts of some thin sections and stained quartz-feldspar slides.

Frosted surfaces of quartz and feldspar grains were determined using the optical microscope using the criteria of crescent-shaped pits also occurring on otherwise glossy surfaces. The count of frosted grains was restricted to grains $>250 \mu \mathrm{m}$ (in rare cases also to $>125 \mu \mathrm{m}$ ) because the frosting process by eolian grain saltation is not clearly developed with smaller size fractions (Bagnold, 1941). The coarse fraction was dominated in Site 370 by artificial mud lumps, which were difficult to distinguish from fecal pellets and naturally redeposited particles of pelagic or deltaic mud sediment. Because of this, the composition of most samples was estimated only semiquantitatively after a quantitative count of a few random samples had been made.

Appendix A summarizes the following results:

1) Grain size: (a) percentage of sand fraction $(>63$ $\mu \mathrm{m})$ per total sample; (b) percentage of coarse silt fraction (44 to $63 \mu \mathrm{m}$ ) per total sample; (c) median size of sand fraction; (d) range of median size of quartz plus feldspar within the sand fraction.

2) Proportions of terrigenous particles, shallowwater biogenous grains, pelagic biogenous components, nonbiogenic shallow-water sediment debris, pelagic sediment debris, fecal pellets.

3) The following calculated ratios (per size fractions as indicated in the respective columns): (a) \% feldspar of total quartz plus feldspar; (b) \% stained quartz of total quartz; (c) \% frosted quartz of total quartz; (d) ratio of quartz plus feldspar to mica.

4) Dominant components in the group "shallowwater biogenous grains."

5) Dominant components in the group "pelagic biogenous grains."

6) Resulting type of sand layer.

\section{Grain Size}

Two main groups of sand layers are distinguished based on the abundance of sand fraction $(>63 \mu \mathrm{m})$ (Figures 4 and 5). Group 1 is composed of clean sand layers from Cores 139-6 and 7 (55\% to 90\% sand), Cores $367-3$ to 5 (75\% to $98 \%$ sand), and Cores $135-\mathrm{SW} 1$ and 2 and $140 \mathrm{~A}-1$ and 2 . A few samples in group 1 have artificial mud contamination which reduces the sand percentages. Group 2 is represented by sands with $5 \%$ to $55 \%$ coarse fraction which are found in Cores 138-1 and 2, Cores 367-1 and 2, Cores 368-17 and 22, and Cores $370-2$ to 5 . These samples may be biased by mud lump contamination. The two groups parallel the grouping by bed-thickness frequency, however, they seem not to be related to bed thickness itself.

The abundances of coarse silt ( 44 to $63 \mu \mathrm{m}$ ) strongly confirm this two-part subdivision (Figure 5). Only minor amounts of coarse silt occur in the sand layers of group 1 (Cores $367-3$ to 5 , generally $0.1 \%$ to $1.0 \%$ silt; Cores of Sites 139 and $140 \mathrm{~A}$ less than $3.5 \%$ to $5.0 \%$ silt; and the lower samples from Core $138-1,2 \%$ to $8 \%$ silt). On the other hand, sand layers of category 2 are characterized by high proportions of coarse silt. Cores $367-1$ and 2, Cores $368-17$ and 22 have $20 \%$ to $31 \%$ silt and Cores $138-1$, top, and $370-2$ to 5 have $6 \%$ to $28 \%$ silt. It must be stressed that the abundance of coarse silt appears to be independent of the position of a sample within a sand layer. Summarizing, many sand layers of group 1 show a double-peaked grain-size frequency distribution, sand layers of group 2 show a simple one.

The median grain diameters of sand layers in group 1 generally range between 140 and $225 \mu \mathrm{m}$, but a few (less than $20 \%$ ) reach extreme values of up to 290 and down to $110 \mu \mathrm{m}$. Median grain sizes of sand layers in group 2 vary between 70 and $100 \mu \mathrm{m}$. However, frequently they are strongly biased towards coarser sizes (up to $500 \mu \mathrm{m}$ ) by abundant indestructible lumps. Another factor for errors in coarse diameters, especially in cores of Site 370 , is a significant proportion of light sand-sized components, e.g., planktonic fossils, compared with the rather clean quartz sands of group 1. Recalculated median sizes of quartz sand always are smaller than 90 $\mu \mathrm{m}$ (Figure 6).

The sand layers of Core 138-1 show a continuous upward decrease in median size (from 113 to $93 \mu \mathrm{m}$ ) (Figure 4). The abundance of sand varies independently of this trend and decreases abruptly from 4 to 3 meters below the top of the core. A general slight upward 
TABLE 2

Coarse Fraction Components Distinguished in This Study

\begin{tabular}{|c|c|c|c|c|c|}
\hline $\begin{array}{l}\text { Clastic } \\
\text { Terrigenous } \\
\text { Components }\end{array}$ & $\begin{array}{c}\text { Nonbiogenic } \\
\text { Shallow-Water } \\
\text { Sediment Debris }\end{array}$ & $\begin{array}{c}\text { Shallow-Water } \\
\text { Skeletal Grains } \\
\text { (Reworked and } \\
\text { Corroded) }\end{array}$ & $\begin{array}{l}\text { Other Biogenic } \\
\text { Components } \\
\text { (Mostly Pelagic) }\end{array}$ & $\begin{array}{l}\text { Pelagic } \\
\text { Sediment } \\
\text { Debris }\end{array}$ & $\begin{array}{l}\text { Miscellaneous } \\
\text { Components }\end{array}$ \\
\hline $\begin{array}{l}\text { Quartz unstained } \\
\text { Quartz stained } \\
\text { Quartz unfrosted } \\
\text { Quartz frosted } \\
\text { Quartz angular } \\
\text { Quartz rounded } \\
\text { Feldspar } \\
\text { unstained } \\
\text { Feldspar stained } \\
\text { Feldspar } \\
\text { unfrosted } \\
\text { Feldspar frosted } \\
\text { Mica } \\
\text { Heavy minerals } \\
\text { Rock fragments }\end{array}$ & $\begin{array}{l}\text { Oöids } \\
\text { Superficial oöids } \\
\text { phosphatic oöids } \\
\text { Faecal pellets, } \\
\text { lithified or } \\
\text { glauconitic } \\
\text { Beachrock, limo- } \\
\text { nitic sand- and } \\
\text { siltstones, partly } \\
\text { rounded and polished } \\
\text { Resedimented } \\
\text { glauconite particles }\end{array}$ & $\begin{array}{l}\text { Algae } \\
\text { Foraminifera } \\
\text { (benthos) } \\
\text { Corals } \\
\text { Bryozoa } \\
\text { Bivalves } \\
\text { Gastropods } \\
\text { Barnacles } \\
\text { Echinoids } \\
\text { Plant fibres }\end{array}$ & $\begin{array}{l}\text { Planktonic } \\
\text { foraminifera } \\
\text { Benthonic } \\
\text { foraminifera } \\
\text { Diatoms } \\
\text { Radiolaria } \\
\text { Sponges } \\
\text { Bivalves } \\
\text { Gastropods } \\
\text { Pteropoda } \\
\text { Ostracodes } \\
\text { Decapods } \\
\text { Echinoderms } \\
\text { Fish remains } \\
\text { Worm shells }\end{array}$ & $\begin{array}{l}\text { Chert } \\
\text { Porcellanite } \\
\text { Laminated } \\
\text { Siltite }\end{array}$ & $\begin{array}{l}\text { Authigenic } \\
\text { autoch thonous } \\
\text { minerals } \\
\text { Iron crusts } \\
\text { Pumice } \\
\text { Fecal pellets }\end{array}$ \\
\hline
\end{tabular}
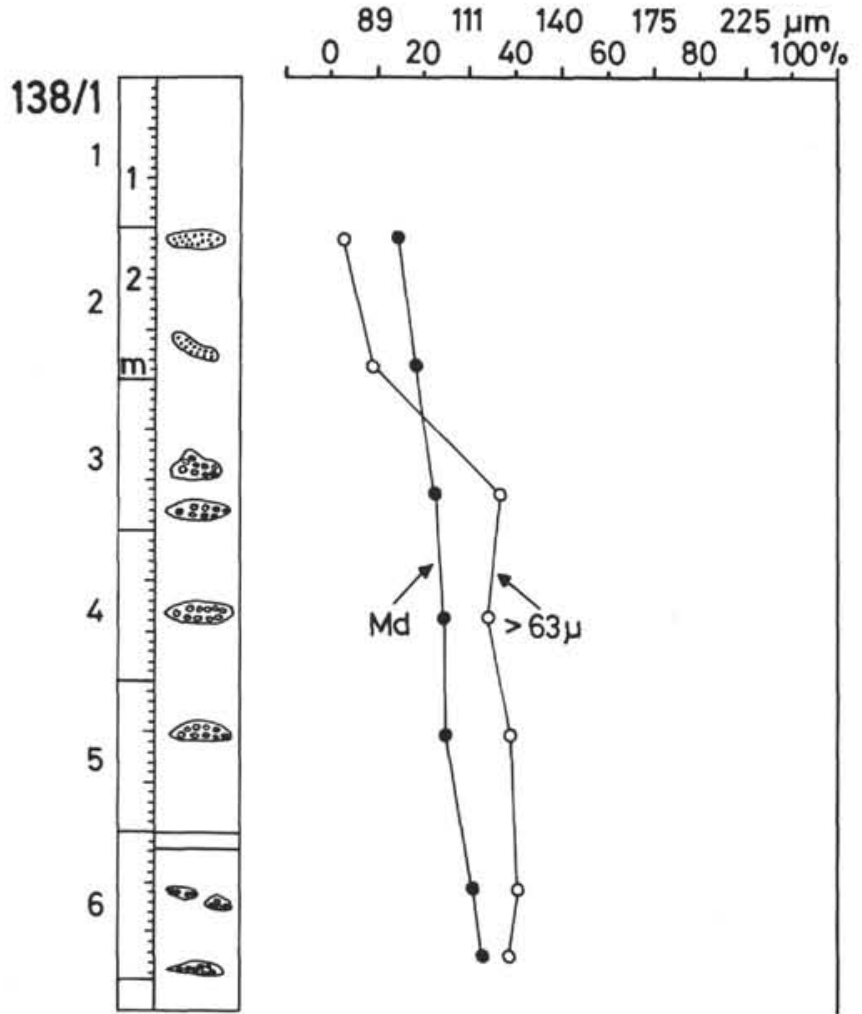

Figure 4a. Core sections showing position of sand layers and grain sizes. Dotted sand layers are muddy and mostly graded. Coarse signature marks clean ungraded sands.

decrease of sand abundance in Core 139-7 is found as well, in spite of an increase of bed thickness. Site 367 shows only one marked change from sand-layer group 1 to 2 between 54 and 17.5 (?12) meters depth, i.e., between upper Pliocene and middle Pleistocene sediments. Site 370 reveals no general trend except for

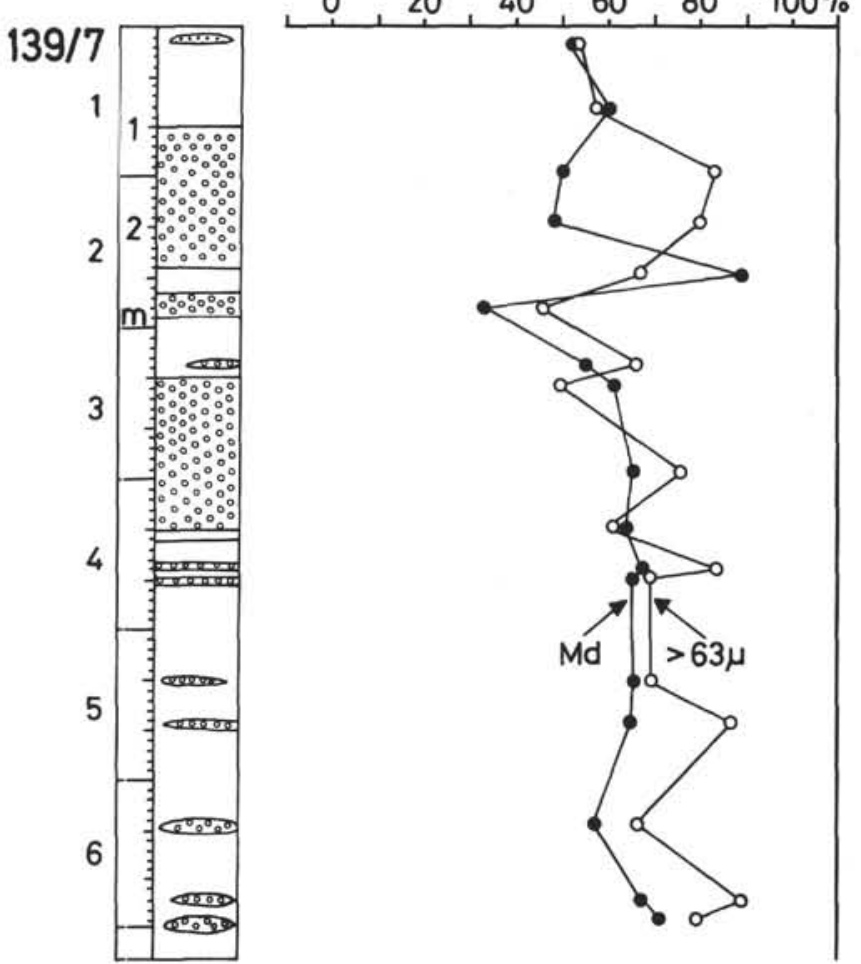

Figure $4 \mathrm{~b}$. Core sections showing position of sand layers and grain sizes. Dotted sand layers are muddy and mostly graded. Coarse signature marks clean ungraded sands.

Core 5 (Oligocene), where sand proportions and median sizes decrease and silt proportions generally increase from bottom to top (17 samples from 28 sand layers in 8-meter-thick sediment core). In summary, a vertical comparison of the sand layers displays only a few significant overall trends of grain size. 

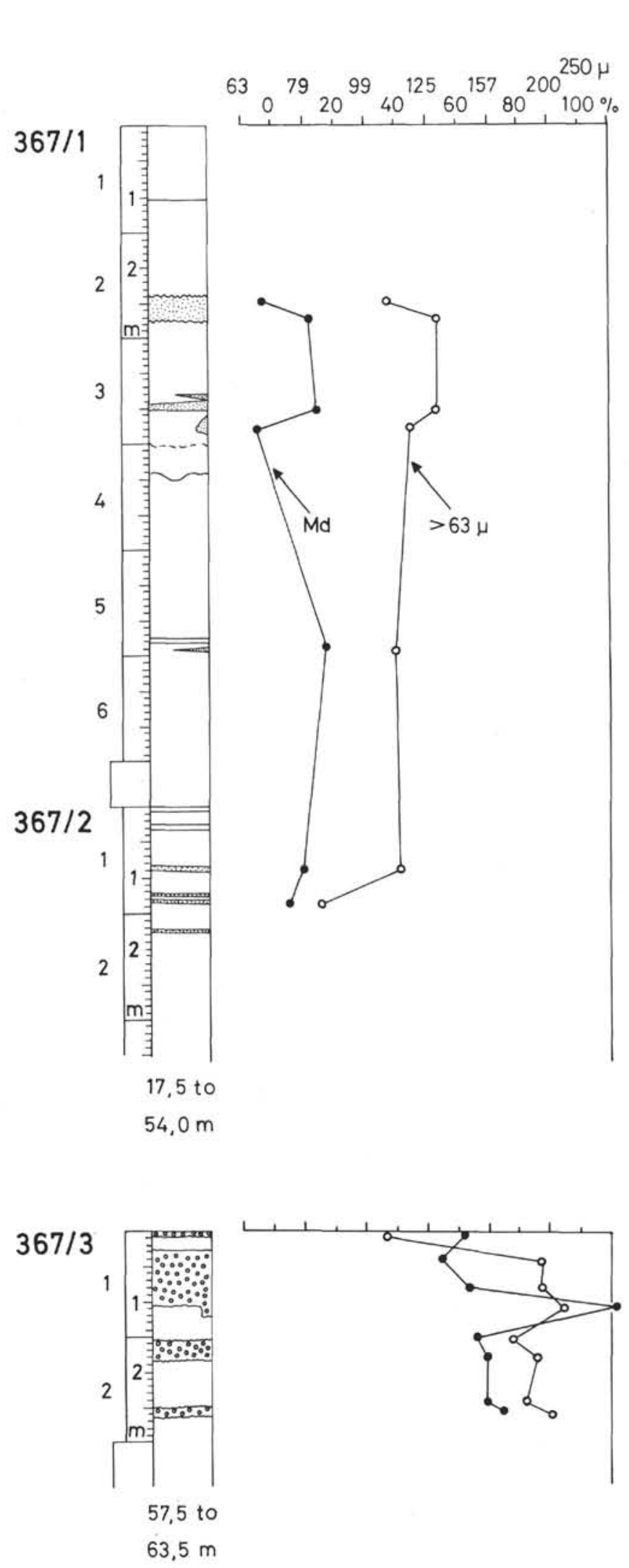

Figure 4c. Core sections showing position of sand layers and grain sizes. Dotted sand layers are muddy and mostly graded. Coarse signature marks clean ungraded sands.

$367 / 4$
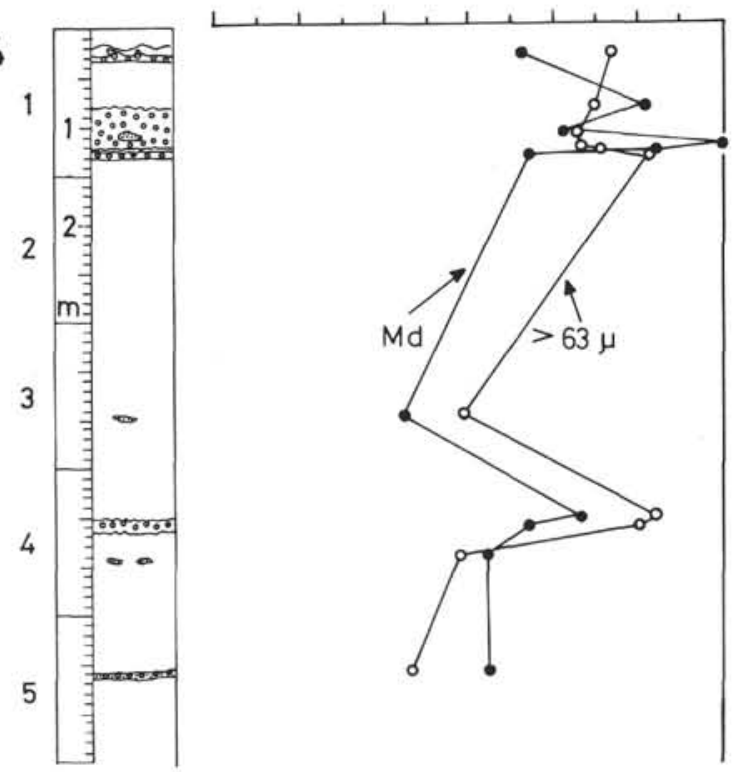

73 to

$150 \mathrm{~m}$ depth
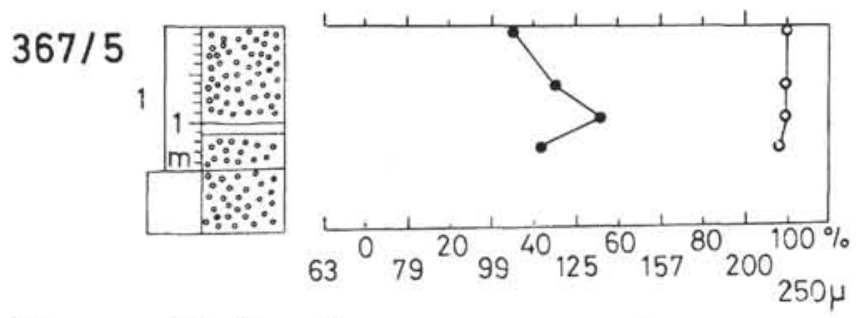

Figure 4c. (Continued).
$370 / 2$

1

22

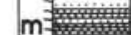

3

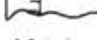

$107,0-$

$207.5 \mathrm{~m}$

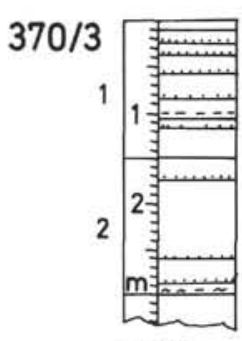

$210,5-$

$217,0 \mathrm{~m}$

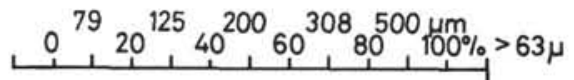

Figure 4d. Core sections showing position of sand layers and grain sizes. Dotted sand layers are muddy and mostly graded. Coarse signature marks clean ungraded sands. 

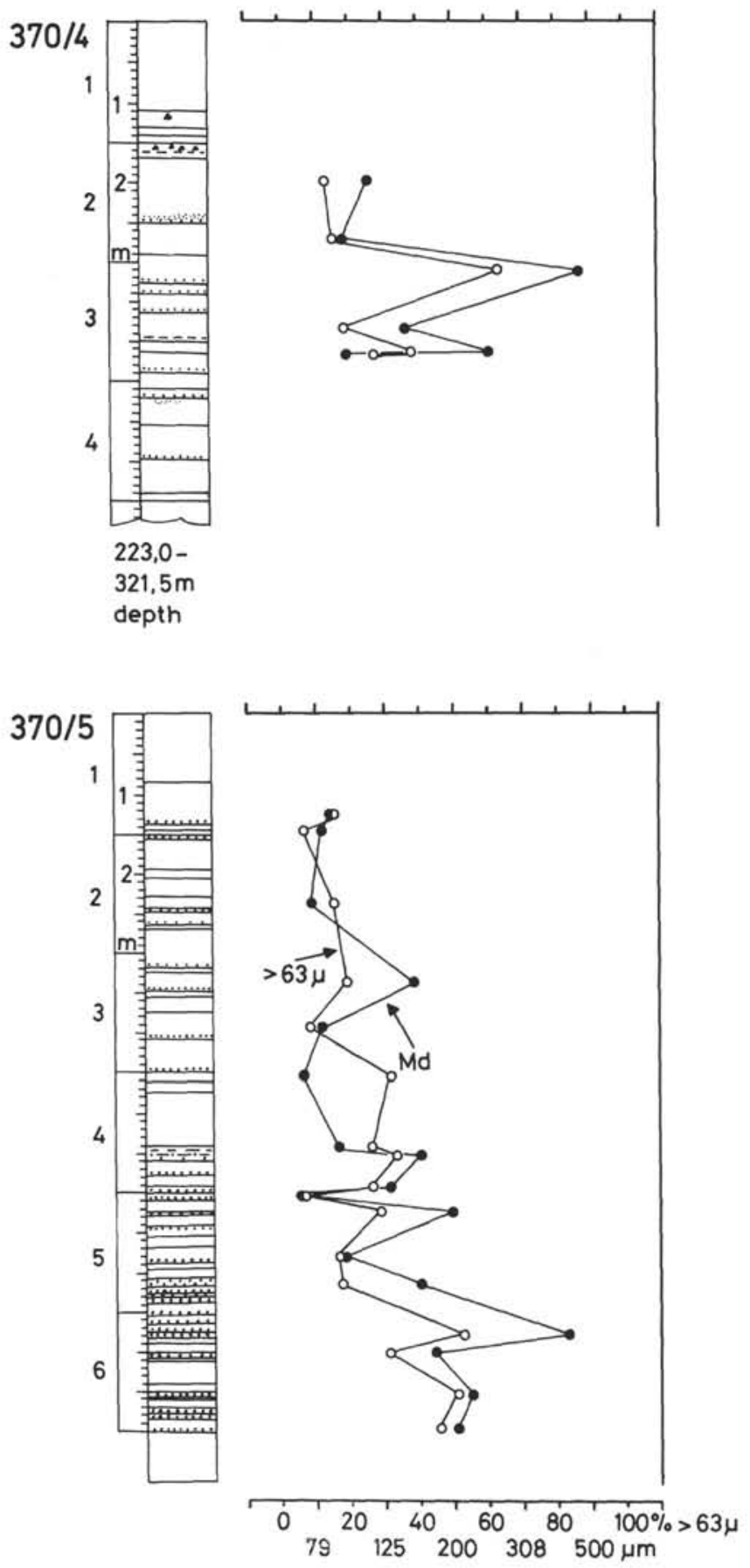

Figure 4d. (Continued).

\section{TERRIGENOUS COMPONENTS}

\section{Quartz and Feldspar}

Quartz and feldspar are the dominant components of sand layers except for Site 370, where resedimented glauconite and biogenic particles dominate many samples and where true proportions are partly obscured by an abundance of mud lumps.

Two groups of sand layers are clearly distinguished by the distribution of median-sand sizes of quartz and feldspar $\left(\mathrm{Md}_{\mathrm{Q}}\right)$. There is a correlation in a majority of cases of the groups with the total sand median sizes
(Figure 6): Fine-sand medians range up to $95 \mu \mathrm{m}$ (layers in Cores 138-2, 367-1 and 2, 368-17, and 370-2 to 5); Coarse medians range from 140 to $290 \mu \mathrm{m}$ (layers in Cores 135-SW1 and 2, 139-6 and 7, 140-1 and 2, and 367-3 to 5). There is a gap in $\mathrm{Md}_{\mathrm{Q}}$ sizes between 95 and $115 \mu \mathrm{m}$ (Figure 6). The gap could be considered to continue up to $140 \mu \mathrm{m}$ because only $5 \%$ of all samples lie between 115 and $140 \mu \mathrm{m}$. The only exceptions to this rule are the sand layers of Site 138 (Core 1), the site farthest from Africa. Generally, only quartz sizes with an optimum transport mobility $\left(\mathrm{Md}_{\mathrm{Q}}=100\right.$ to 120 $\mu \mathrm{m} ;$ Hjulström, 1939) are absent in the sand layers.

The abundance of medium sand-sized feldspar is higher than that in the coarse sand-sized grade. Highest ratios of feldspar to quartz plus feldspar occur in upper Pliocene arkosic sands (Cores $367-3$ to $5:>500 \mu \mathrm{m}$, $10 \%$ to $30 \% ; 250$ to $500 \mu \mathrm{m}, 17 \%$ to $35 \%$ feldspar). The early Miocene samples of Cores 138-1 and 139-6 and 7 are rather mature quartz sands ( 125 to $500 \mu \mathrm{m}, 10 \%$ to 23\% feldspar; also see Berger and von Rad, 1972). The general association of feldspar to well-rounded quartz suggests the feldspars have a continental origin (see section on facies).

Hematite stains and coatings are abundant on both quartz and feldspar grains. This feature was termed "desert quartz" by Radczewski (1939) for Holocene and Pleistocene sediments. More feldspars are stained than quartz by some $20 \%$ to $40 \%$, and generally the coarser fractions show staining more than the finer fractions. Most coarse desert quartz is found in upper Pliocene sands of Cores $367-3$ to 5 (Figure 7). The abundances of coarse desert quartz are as high as $90 \%$ and resemble those of recent dunes (Sarnthein and Diester-Haass, 1976). A smaller but still significant proportion of these grains occur in late Oligocene to early Miocene sand (sample group C and D). Fine-sand quartz (63 to $125 \mu \mathrm{m})$ in upper Miocene, Pliocene, and Pleistocene cores is intensively stained, regardless of grain-size distribution. Stained fine quartz is generally rare in lower Miocene and Oligocene cores, except for Cores 139-7 and 370-4. The lower Miocene samples of categories $\mathrm{G}$ and $\mathrm{H}$ (Figure 7) are almost unstained. The amount of desert quartz only rarely forms continuous trends within a single core profile. For example, in Core 138-1 the amount of stained quartz (125 to $250 \mu \mathrm{m}$ ) decreases continuously from bottom to top. In Core $139-7$ the desert quartz proportion increases in all sand-size fractions from Sections 6 to 3, and then decreases to Section 1. The fine-sand layers of Site 370 reveal a continuous increase of the stained quartz fraction from Oligocene to upper middle Miocene.

The roundness of quartz grains is closely related to grain size, Well-rounded quartz grains are most dominant in the coarse size fractions $(>250 \mu \mathrm{m})$ in all samples, except for those of Cores 135-SWI and 2 . Frosted quartz grains have a distribution pattern similar to the stained grains and the feldspar percentages. Frosted quartz grains also indicate a continental desert origin for the sand layers. Forty-five to $70 \%$ of the quartz grains $>500 \mu \mathrm{m}$ are frosted in Core $367-4$, but the abundance decreases continuously to $20 \%$ at the top of Core $367-3$. Core $139-7$ has up to $25 \%$ frosted quartz grains. For quartz grains $>250 \mu \mathrm{m}$, 


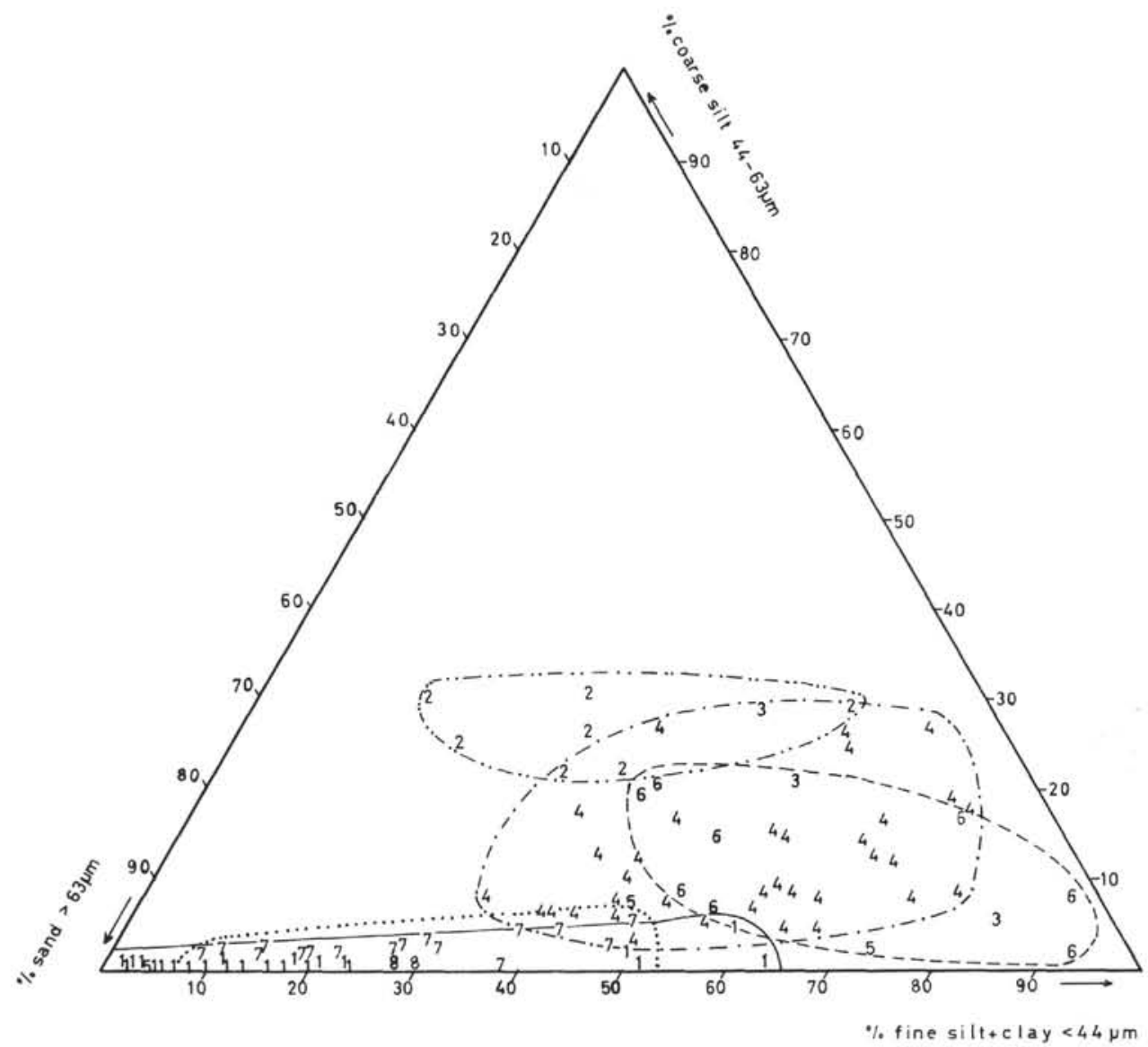

Figure 5. Clay-coarse silt-sand triangle of sand-layer samples, based on sieve analyses. $1=$ Cores 367-3 thru 5, $2=367-1$ and 2, $3=368-17$ and 22, $4=370-2$ thru 5 , $5=135-S W 1$ and $2,6=138-1,7=139-7,8=140 A-1$ and 2 .

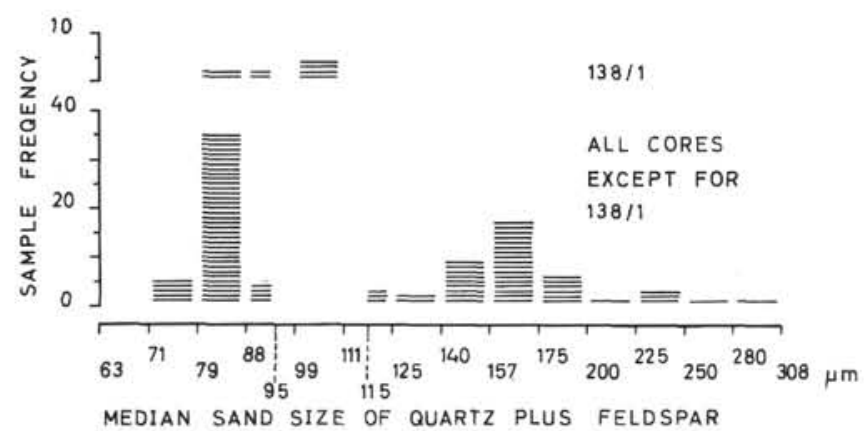

Figure 6. Frequency distribution of median sand size quartz plus feldspar. Note the distinct gap between 95 and 115 $\mu \mathrm{m}$.

the numbers of frosted grains are generally smaller: $24 \%$ to $43 \%$ in Core $367-4,13 \%$ to $32 \%$ in Core $367-3$, and up to $30 \%$ in Core 139-7. The quartz fraction $>125$ $\mu \mathrm{m}$ has $7.5 \%$ to $20 \%$ frosted grains in Core $139-7$, and $5 \%$ to $20 \%$ in Core $138-1$. The bases of sand layers are generally enriched in frosted quartz grains with up to $10 \%$ in abundance.

\section{Mica}

The abundance of terrigenous mica is correlated to the Md because of grain-size sorting on the sea floor (Figure 8). Accordingly, less than $0.01 \%$ mica is found

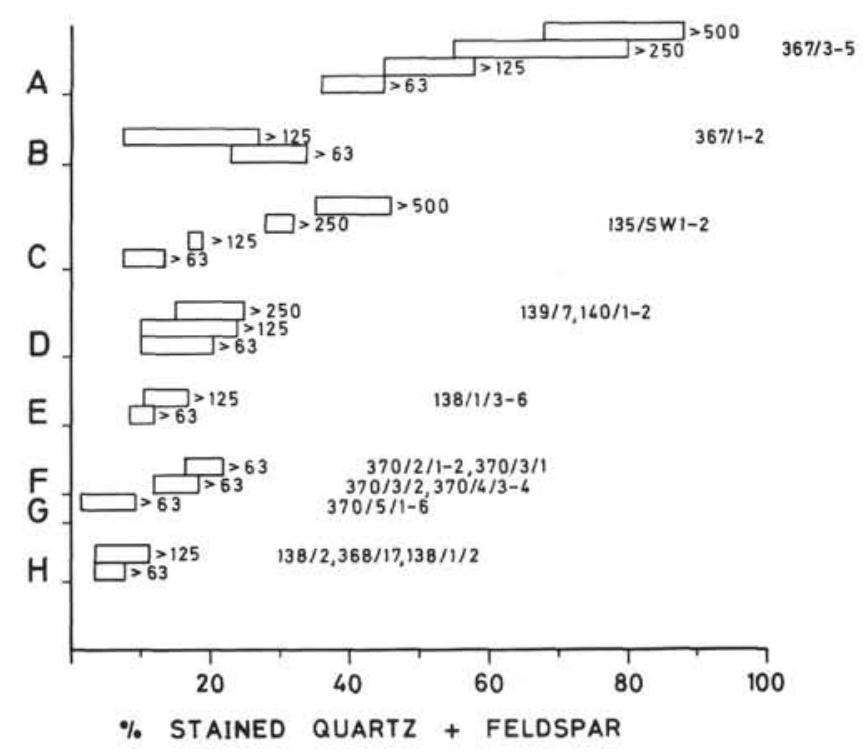

Figure 7. Abundance of stained quartz plus feldspar in total quartz plus feldspar, as related to different grain size fractions. Generally, the staining increases with increases in grain size, except for Cores 367-1 and 2. Also the increase of staining in the fine sands of Site 370 towards the late Neogene can be interpreted as an increase of influence of (reworked) Sahara dust. 


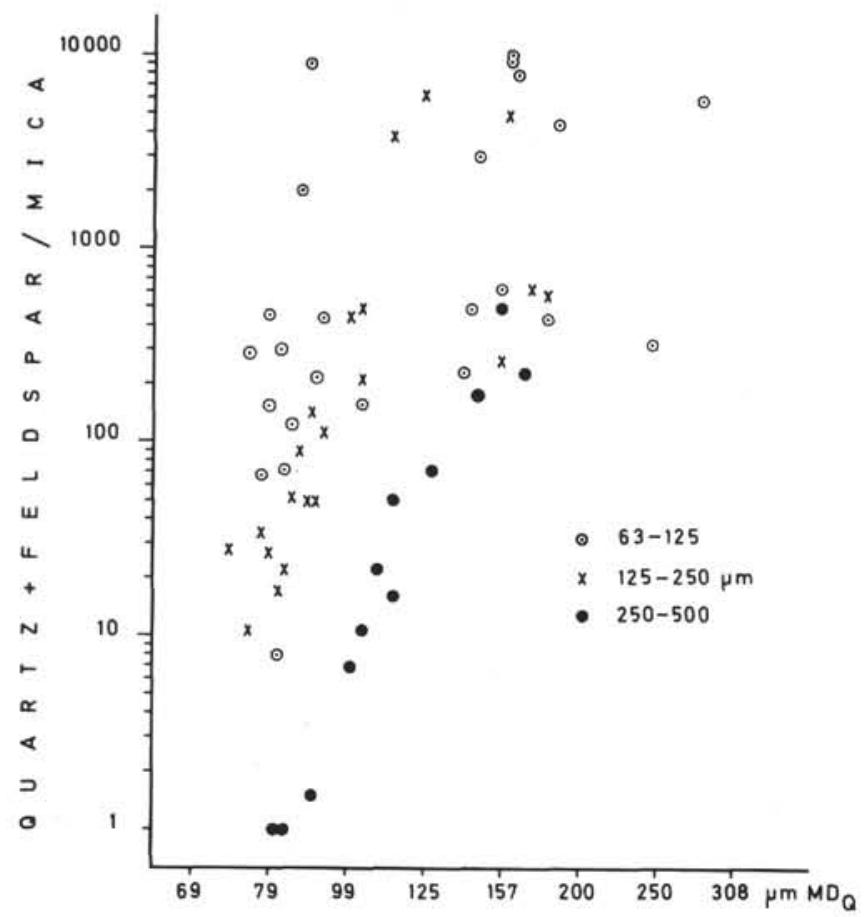

Figure 8. Quartz plus feldspar to mica ratio, related to the median sand size of quartz plus feldspar. Broad scattering of data in the ratio range of 400 is due to the grain count 300 to 500 where single mica grains have been considered as traces.

in sand layers of Cores 135-SWI and 2, 139-7, 140A-1 and 2 , and $367-3$ to 5 . One to $4 \%$ mica occurs in the remaining samples. The data suggest that a continental source did not influence the quartz to mica ratio.

\section{Heavy Minerals}

Heavy minerals and iron oxides are a common constituent $(0.15 \%$ to $2.5 \%)$ of the very fine sand ( 63 to $125 \mu \mathrm{m})$ and coarse-silt fractions of the coarser grained sample group. Iron oxides frequently are ball-shaped indicating a mechanical rounding by reiterative rolling transport at shorelines.

\section{Shallow-Water Sediment Debris}

Nonbiogenic sand particles persistently occur which are characteristic of those formed in very shallow water environments, such as those known from the modern Sahel and Sahara shorelines in Senegal and Mauritania (Koopmann et al., in preparation; Schwarz et al., 1975). The principal particles of this group are quartz grains with superficial, frequently blackish oöid coatings, and beachrock debris (calcite-cemented quartz sandstone), both of which are characteristic of coastal regions of subtropical, arid coasts. Lithified and rounded limonitic or glauconitic fecal pellets, debris of limonitic siltites and sandstones also are abundant. The latter frequently show rounded and polished surfaces as well. Limonitic sediment particles from Holocene sediments are common in the semiarid transitional zone. Hematite coatings on desert quartz from this zone easily become mobilized in stabilized dunes and winddust deposits by temporary fresh-water influence.
Subsequently, the mobilized iron is reprecipitated as limonite cement. Finally, phosphatic oöids and glauconitic-mudstone particles are included in the shallow-water particle group, because the primary formation of glauconitic constituents seems to be commonly associated with environments of arid to semiarid coasts (e.g., Birch, 1973; Lange and Sarnthein, 1969). Mature rounding and polishing of the glauconite grains suggests multiple reworking (e.g., by transgressions) and placer-like enrichment, such as are common at beaches, before the particles finally become buried in the deep sea.

The persistent fractions of shallow-water sediment debris can serve as reliable tracers for the quartzfeldspar sands to a shoreline origin even if they contribute generally less than $2 \%$ to $3 \%$ to the sand layers. Limonitic siltites and sandstones, as well as glauconite grains, occur in all sand layers, except for Site 368 (Figure 9). Glauconite is most abundant in the north, in Core $370-5$ (up to $33 \%$ ); the maximum abundance of limonitic sediment debris is from middle Pliocene sediments of Cores $367-4$ and 5. Oöids and beachrock debris are confined to sand layers from the southern sites (Sites 138 to 367), except for Cores 367-1 and 2 . However, no conclusive time-transgressive trend of distribution is found because the abundance of sand layers is not sufficient.

The fine-grained, silty sand-layer group (Figure 6) of Cores $367-1$ and 2 also can be characterized by an extraordinary abundance of fecal pellets and plant fibers. Both can be interpreted as tracers for redeposition of deltaic shelf sediments (Sarnthein, 1971; Sarnthein and Walger, 1973).

Debris from metamorphic rocks contributes an unusually large fraction (20\% to $35 \%)$ to the sands of Site 135 . These grains may be the product of shallowwater erosional processes. Rare admixtures of metamorphic rock fragments also occur in Cores 139-6 and 7.

\section{Pelagic Sediment Debris}

The pelagic sediment debris consists of angular grains of chert, porcellanite, microlaminated siltite, nanno chalk, foram-nanno chalk, and limestone. Their composition is usually somewhat different from the local pelagic fine-fraction background such as found in fine-fraction lumps and in the overlying and underlying sequence. The abundance is generally less than $1 \%$ to $4 \%$ and is randomly distributed. Higher values of $7 \%$ to $25 \%$ are found in the sands of Cores 138-2, 367-5, 36822 , and $370-2$ to 5 .

The major proportion of pelagic particles is obviously derived from the neighboring continental slope and might help to decipher the erosion history of its canyons (Sarnthein and Diester-Haass, 1976).

\section{Authigenic Minerals}

The sand-sized authigenic minerals include gypsum, pyrite, calcite, and quartz (glauconite and phosphate are regarded as displaced shallow-water particles). Crusts of iron oxides are almost impossible to distinguish from contaminations by abrasion of particles from the drill string. Similarly, gypsum 
mio.yrs.

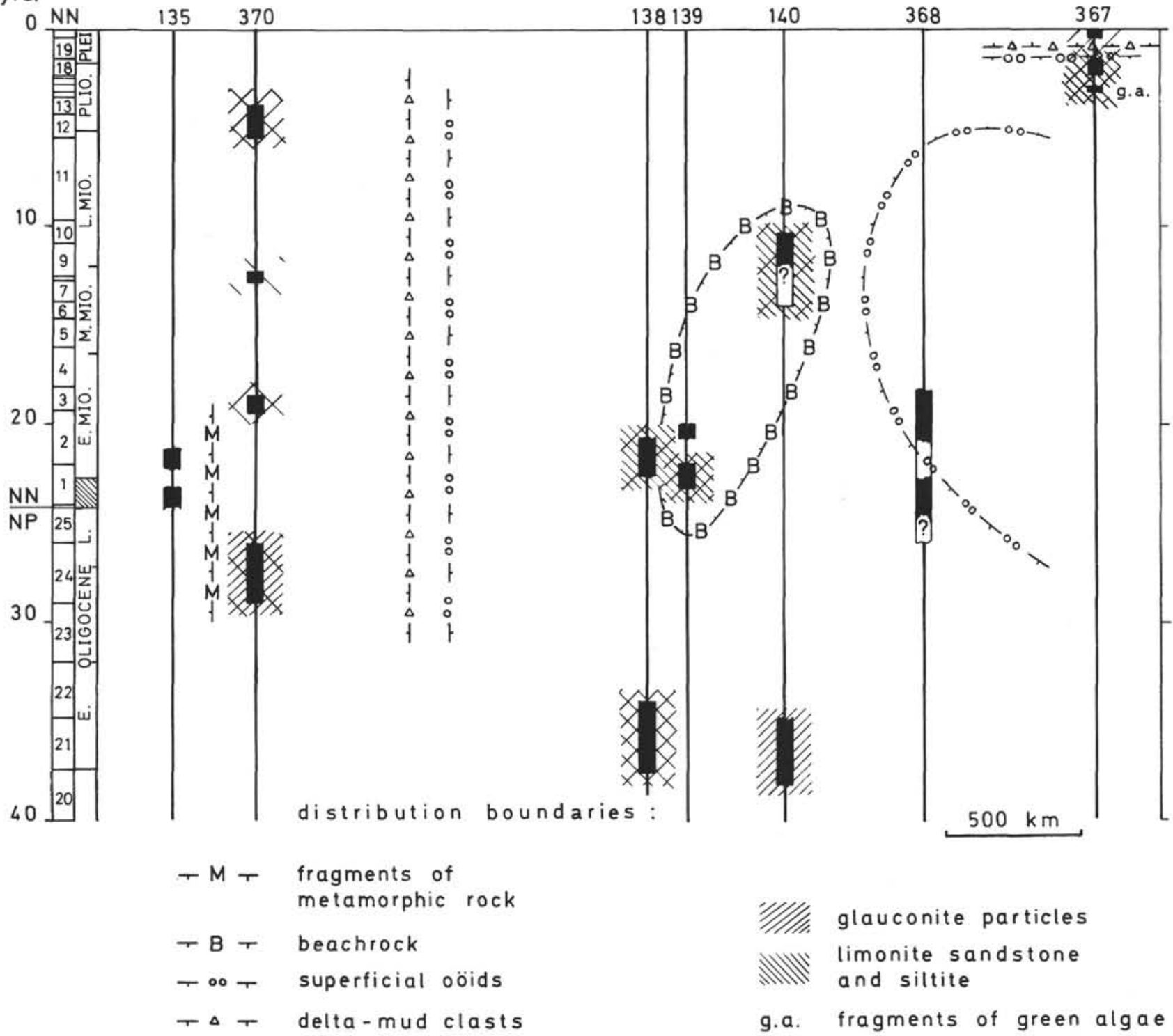

Figure 9. Regional and stratigraphic patterns of shallow-water non-biogenous grains. Little hooks at lines point to area of component abundance. Narrow spacing of hatchure refers to higher abundance.

crystals may have grown after the cores were stored in the repository because they occur predominantly in the older cores of Leg 14.

Quartz grains with secondary silica overgr swth are found in early Miocene sediments of Cores 139-6 and 7 (see Berger and von Rad, 1972). These grains are frequently associated with calcite cement, which is confined to these two cores, and represent displaced beachrock cement and autochthonous cementation of the sand layer in Core 139-6. Authigenic silica also occurs as void fillings in skeletal grains and as euhedral quartz grains in Cores 367-1, 368-22, and 370-2. Pyritized skeletal grains and voids are common in the fine-grained sand layers, especially in Core 367-2 (up to $46 \%$ ) and in Cores $370-2$ to 4 .

\section{Volcanogenic Grains}

A few olive-brown pumice fragments in Core $367-4$, Section 4 are the only volcanogenic components from the sites studied. The grains are wEll rounded and are medium and coarse sand-size classes (up to $2.0 \mathrm{~mm}$ ). The pumice probably marks an early active phase of the cape Verde volcanism (lower NN 18 zone, corresponding to 2 m.y.B.P.) (Hebrard et al., 1969).

\section{Shallow-Water Biogenous Components}

In addition to the fragments of shallow-water sediment, the majority of sand layers contains a fraction of coarse-grained, benthonic shallow-water fossils (commonly less than $1 \%$ to $5 \%$; Appendix A). Their primary origin is clearly identified by, for instance, thick shell structure or by the state of preservation. ${ }^{2}$ As an example, many pelecypod shells

${ }^{2}$ Most of the distinguishing criteria was based on the author's experience with shallow-water sediments off northwest Africa and elsewhere (Sarnthein, 1971). The percentage figures on shallow-water fossils in Appendix A represent minimum values. 
are coarse and intensely corroded by mechanical reworking or by onsets of beachrock-like cementation with other sediment grains. Other shells show a weathered appearance and are perforated by blackish microalgal borings filled with goethite or glauconite. They are like "mummies" which are characteristic of the modern and sub Holocene sediments along the shorelines and at a few meters water depth off the Western Sahara desert (Koopmann et al., in preparation).

Single crystals from the prismatic layer of Pinna sp. are particularly common in the fine-sand layers of Cores $367-1$ and 2 . The skeletal association as a whole corresponds to the "foramol" group of Lees (1975) (dominant groups: benthic foraminifers, pelecypods, and barnacles), which is typical of the temperate-water shelf environment. Occasionally, large foraminifera, such as Amphistegina sp. (Cores 367-3, 370-2, 140-1, Section 1), and green-algae fragments (Core 367-5) indicate slightly more favorable temperature conditions close to the ones of Lees' "chloralgal" group.

The state of shell preservation was not classified quantitatively. However, distinct dissolution patterns were noted on benthonic foraminifera, pelecypods, and barnacles. Areas such as a damaged (aragonitic) nacreous layer of a bivalve, an etched (calcitic) balanid scutum, or missing keels and holes of (calcitic) tests of benthonic foraminifera were scanned for effects of dissolution. Preservation is generally poor in the sand layers of Core 139-7, sections 3 to 6, in Core 140A-2 (silicified skeletal hardparts only) and in Cores 367-3 to 5 , with a maximum of dissolution in Core 367-4 (no bivalve shells). The absence of shallow-water fossils may be either a primary or a dissolution feature in Cores 138-2 and 368-17 and -22. Well-preserved skeletal grains occur in the fine-grained sand layers of Cores 138-1, 367-1 and 2 (e.g., aragonite needles of Pinna sp. from shelf sediments) and Cores 370-2 to 5 . There appears a salient difference in the preservation pattern of hard parts taken from fine-grained and from coarser-grained sand layers due to a different porewater circulation.

\section{Pelagic Biogenous Components}

"Pelagic" biogenic components form a variable proportion of the sand fraction (Appendix A). Most are of planktonic or nektonic origin. The few benthonic particles either consist of characteristic deep-water species (e.g., foraminifera) or of forms which do not indicate a formation in a shallow-water environment either by shell structure or by shell preservation.

Siliceous and apatitic particles (radiolarians, diatoms, fish remains, and sponge spicules) dominate the pelagic fossil fraction in many sand layers of Oligocene and early Miocene age (Appendix A, Figure 10). Carbonate fossils, such as planktonic and benthonic foraminifera, ostracodes, and pelecypods, are dominant in the remaining sand layers of various ages. The distribution pattern is difficult to interpret because the sample coverage from the sites is poor (Table 1), and because the vast majority of these pelagic fossils are probably reworked from shallower slope environments. However, the Oligocene to early
Miocene and regional concentration of siliceous skeletal grains and fish remains at Sites 138, 139, and 368 is striking because it seems to be unrelated to the paleodepth of the water (Figure 2a). Perhaps this concentration of siliceous material is related to upwelling phenomena off western Africa, such as observed in the Holocene by Diester-Haass (1976, and this volume).

There is some doubt in a deep-sea environment interpretation for the benthonic foraminifera and ostracodes that occur in abundance in the sands of Cores 367-1 and 2 (Appendix A). For instance, the ostracodemollusc ratio ranges from 0.5 to 2 , the ratio of benthonic foraminifera and molluscs between 2 and 100. Without knowing their species composition, and only on the basis of their large proportions in the sediment, both fossil groups generally can be regarded as rather indicative of prodeltaic inner-shelf environments (personal observations at modern Senegal delta; Sarnthein and Walger, 1973). Some features of the sand samples which support this interpretation are summarized in the next section.

\section{A GENETIC CLASSIFICATION OF SAND LAYERS}

Deposition by gravity-driven downslope density flows and deposition by contour currents parallel to the slope are two basic modes conceivable for the formation of terrigenous sand layers in the deep sea (e.g., Hollister and Heezen, 1972; Bouma and Hollister, 1973; Carter, 1975). To complicate matters, the material which comprises a turbidite can be derived at a passive continental margin from either a fluvial or an eolian-dune sediment source and the sediments of both can be modified by intercalated long-shore transport phases (Sarnthein and Diester-Haass, 1976). The turbidite composition is further differentiated by a proximal or distal place of deposition (numerous titles since Bouma, 1962). Contour currents will also rework turbidites and create mixed facies types. Finally, during arid conditions, extremely vigorous off-land storms can supply coarse material directly to the sea bottom forming fine-sand beds, but these are confined to the most proximal continental margin (Sarnthein and Diester-Haass, 1976).

The sand layers of all cores are tentatively classified in Figure 11, Table 3, and Appendix A, into various categories using structural, textural, and compositional features and Holocene analogs from West Africa, such as are summarized and defined by Fritz and Pilkey (1975) and Sarnthein and Diester-Haass (1976). Eolian dunes and fluvial deltas can be clearly distinguished as a source of turbidites by the different grain-size frequency groups and by different abundances of feldspar, frosted and stained quartz, fecal pellets, plant fibers, and faunas. A greater or lesser abundance of desert-sand features further differentiates the proximal eolian-sand turbidites of Cores $367-3$ to 5 and 139-6 to 7. Whether these sediments are a result of different amounts of reworking by long-shore drift or to a different maturity of the desert sands is unknown.

The significant component of angular, fine-gravel fraction in Cores 135-SW1 and 2 excludes a dune origin, but it does not necessarily argue for a delta 


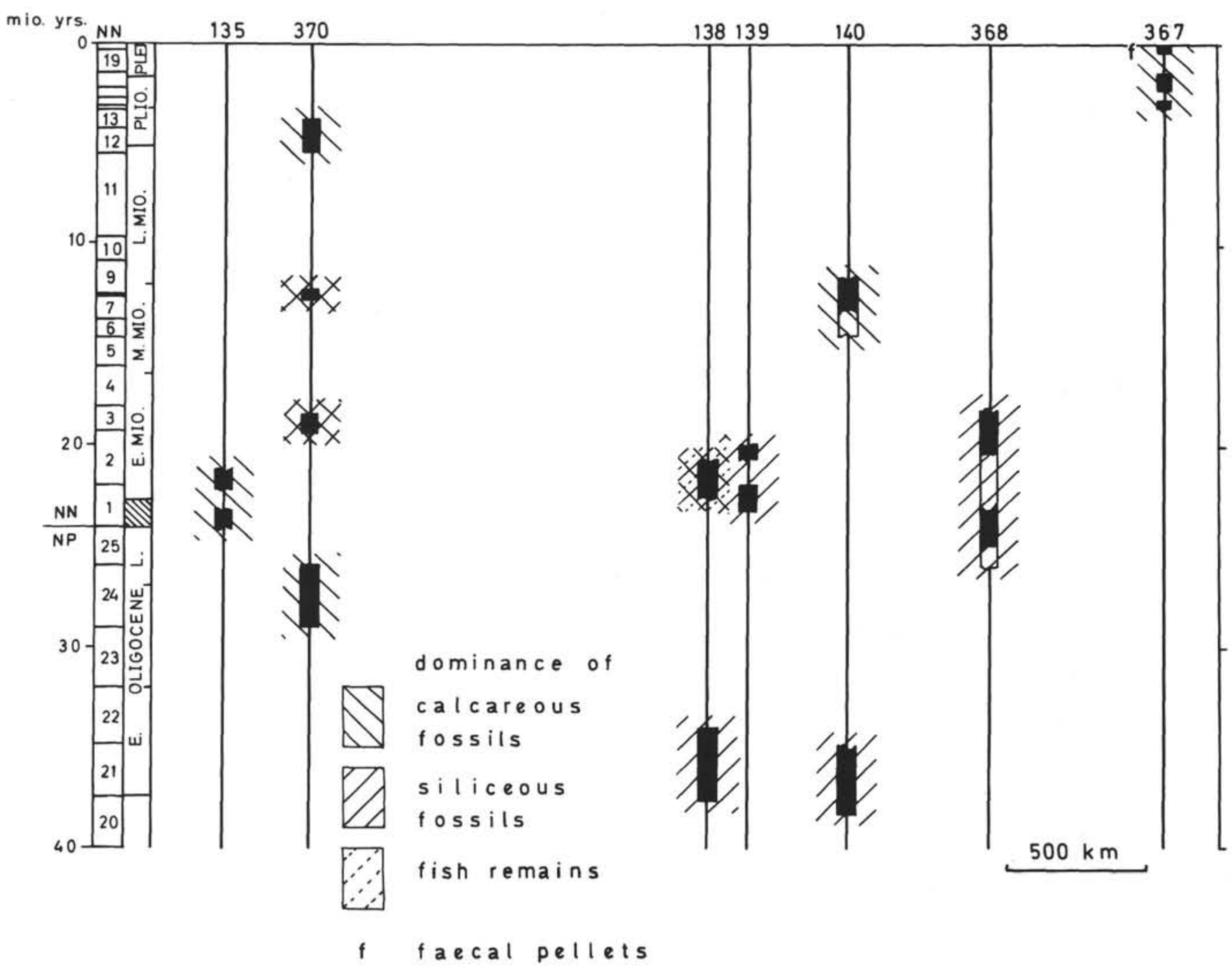

Figure 10. Regional and stratigraphic distribution of dominant pelagic biogenous grains.

source. The gravel may be a product of cliff erosion during an early Miocene transgression in the northern Atlas.

Occasionally, difficulties arise when separating the distal facies of ungraded eolian-sand turbidites from contourites. Contourites in this region should have finer median grain size, higher quartz-to-feldspar ratios, a general absence of shallow-water fossils, and rare desert-quartz features relative to turbidites. Heavy minerals should have a similar distribution in both sediment types. Only the well-rounded, ball-shaped specimens of iron oxides argue for a beach derivation of many sand beds.

In summary, Table 3 shows a suite of features which can be regarded as not significantly influenced by grainsize sorting during transport and as indicative of the source environment. These include the proportions of feldspar, stained and frosted quartz, the composition of reworked shallow-water fossils and nonbiogenous grains, and to a lesser extent the abundance of plant fibers and fecal pellets, and the differences in fabrics. Eolian-sand turbidites lack any gradation structures because of the high degree of sorting of their source material, i.e., the dune sands.
Of all sand-facies types, the eolian-sand turbidites are the only layers with high porosity (some $40 \%$ to $55 \%$ ) on the West African continental rise. The importance of their potential storage capacity for hydrocarbons has been proved by a high initial gas content, which was described from Core 139-7 by Hayes, Pimm, et al. (1972).

\section{HISTORY OF NEOGENE PALEOENVIRONMENT IN SAND LAYER-SOURCE AREAS}

\section{The Model}

The West African continental margin displays a simple semi-actualistic model on the formation of fluvial- and eolian-sand turbidites (Sarnthein and Diester-Haass, 1976), which is extended to the Neogene in Figure 11. Summarizing the model, both the generation and the composition of the turbidites are controlled by the alternating regimes of glacial and interglacial stages, which are effective in three major aspects: (1) Any higher frequency of turbidity currents is connected to glacial periods with low sea level. At these times terrigenous sediments, especially dune sands, can be supplied directly to a shoreline close to 


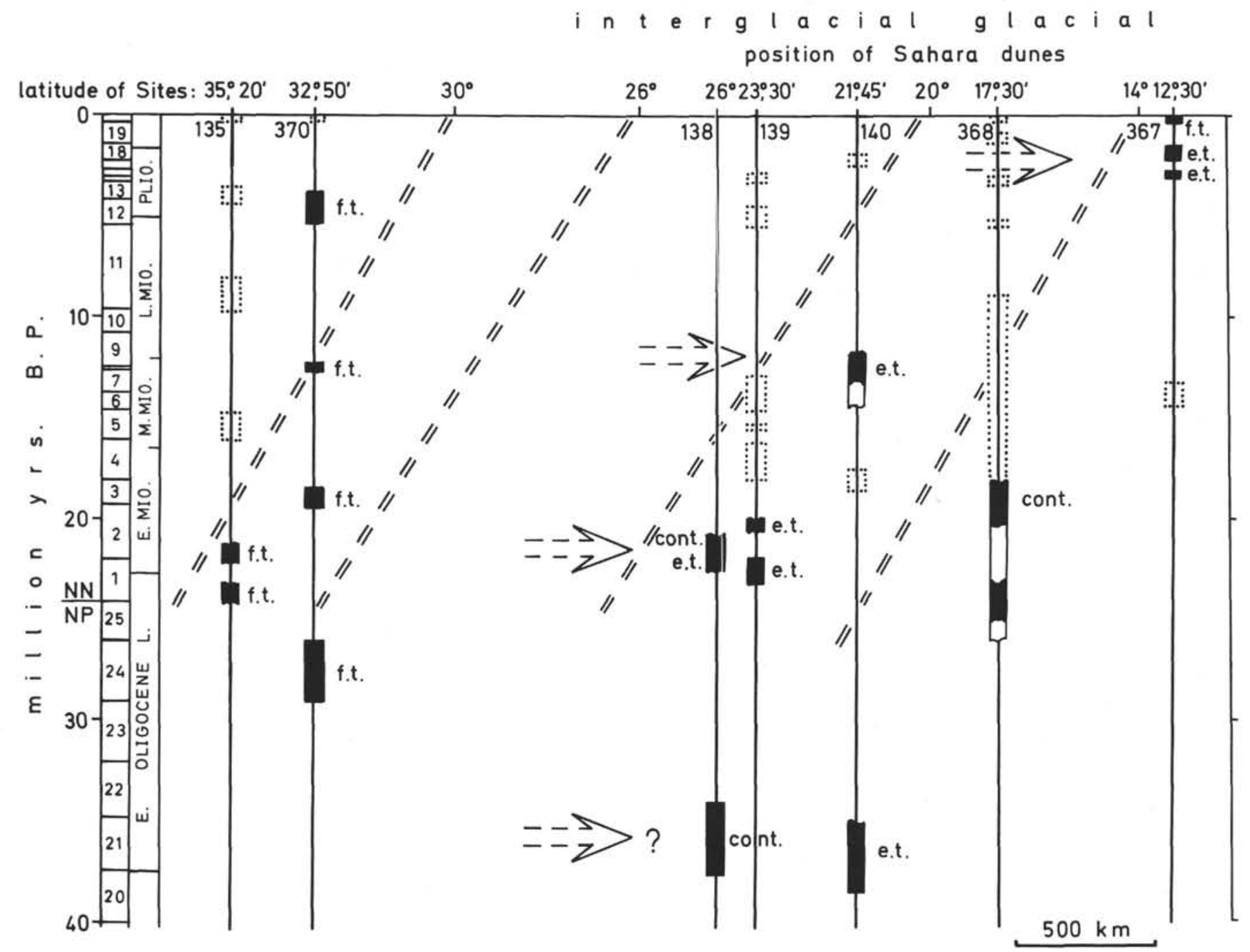

Figure 11. Regional and stratigraphic distribution of different types of sand layers: e.t. = eolian-sand turbidites, f.t. = fluvialsand turbidites, cont. = contourites. Cores at dotted positions are devoid of sand layers. Hatched oblique lines mark the time-transgressive shift of latitudes as indicated on top of the figure. Arrows mark phases with major frequency of turbidite events.

the shelf edge and are particularly subject to slides down the slope (numerous titles since Fairbridge, 1947; Ericson et al., 1961). (2) The paleoclimatic stages determine the rapidly shifting position of the major humid and arid belts. For instance, active desert dunes are confined to zones of $<150$, and mostly $<50 \mathrm{~mm}$ precipitation. The climate belts, in turn, are reflected by the different types of fluvial- and eolian-sand turbidites on the continental rise (Table 3). (3) Eolian-sand turbidites give further evidence of a strong and dominant offshore wind system, mostly Trade Winds, which are responsible for the extensive dune-sand transport towards the shore. Glacial stages apparently resulted in an increase in the vigor of the Trade Winds and in a shift of the whole "Wheel-Round-Latitude" system towards the south by some $6^{\circ}$ of latitude (e.g., Fairbridge, 1965; Elouard et al., 1969; Parkin, 1974; Diester-Haass, 1975). Of course, this information on paleoclimate can only be extracted from the turbidites if the course of their transport channels is sufficiently known. The residence time of the desert material on the sea bottom from crossing the shore line to its final deposition as a turbidite is probably short because the dune sand once displaced as a turbidity current will not undergo this mode of high energy transport a second time. Intermediate depositional phases in canyons are also rather improbable on a large scale (details in Sarnthein and Diester-Haass, in press).

However, a reconstruction of Neogene environments at first requires additional information. It requires at least a crude approach in reconstructing the shift of geographic latitude as suggested by lithospheric plate motions. Figure 11 shows a palinspastic reconstruction using the models of Franchetau (1970). This model gives an overall northward shift of Africa by some $6^{\circ}$ to $7^{\circ}$ within the past 20 to $22 \mathrm{~m} . \mathrm{y}$.

\section{Neogene Phases of Low-Sea Level and Southward Shift of the Sahara Belt}

The eolian-sand turbidites clearly occupy a timetransgressive zone of latitudes (Figure 11), that forms a natural extension of the late Pleistocene synglacial 
TABLE 3

\begin{tabular}{|c|c|c|c|c|}
\hline \multirow[b]{2}{*}{ Sand Layer Type } & \multicolumn{4}{|c|}{ Sandy Turbidites From } \\
\hline & Contourites & River Deltas & $\begin{array}{c}\text { Eolian Dunes } \\
\text { (Proximal } \\
\text { Deposition) }\end{array}$ & $\begin{array}{l}\text { Eolian Dunes } \\
\text { (Distal } \\
\text { Deposition) }\end{array}$ \\
\hline Examples & $\begin{array}{c}138-1 / 2,138-2 \\
368-17, ? 367-4 / 3\end{array}$ & $\begin{array}{c}367-1 \text { and, } 370-2 \\
\text { to } 5, ? 135-S W 1 \text { and } 2\end{array}$ & $\begin{array}{l}139-6 \text { and } 7, \\
140 \mathrm{~A}-1 \text { and } 2 \\
367-3 \text { to } 5\end{array}$ & $138-1 / 3$ to 6 \\
\hline $\begin{array}{l}\text { Bed thickness }(\mathrm{cm}) \\
\text { Sedimentary structures }\end{array}$ & $\begin{array}{l}<1-6 \\
\text { Ungraded sand } \\
\text { lenses }\end{array}$ & $\begin{array}{l}\text { Mostly }<1-6 \text {, up to } 35 \text {, } \\
\text { ungraded and graded, } \\
\text { partly laminated, }\end{array}$ & $\begin{array}{l}>1-6, \text { up to } 150 \\
\text { Massive, structurel } \\
\text { graded, unlaminate } \\
\text { grading, }\end{array}$ & $\begin{array}{l}6-12,5 \\
\text { less, some un- } \\
\text { ed coarse-tail }\end{array}$ \\
\hline$\%>63 \mu \mathrm{m}$ & $<5-30$ & $6-60$ & $35-97$ & $34-40$ \\
\hline$\% 44-63 \mu \mathrm{m}$ & Up to 30 & $3-31$ & $0-5$ & $8-20$ \\
\hline Gravels & No & occasionally (S.135) & No & No \\
\hline $\begin{array}{l}\text { Md grain size } \\
\text { of quartz plus feldspar } \\
\text { in sand fraction }(\mu \mathrm{m})\end{array}$ & $70-90$ & $\begin{array}{l}70-95 \\
\text { (Site 135:500-1000) }\end{array}$ & $115-300$ & $90-115$ \\
\hline $\begin{array}{l}\text { Quartz-feldspar ratio } \\
(\mathrm{x}: 1)(125-250 \mu \mathrm{m}) \\
(250-500 \mu \mathrm{m})\end{array}$ & High: $\begin{array}{c}5-250 \\
-\end{array}$ & $>70$ & $\begin{array}{l}4,3-9,0 \\
2,5-9,0\end{array}$ & $\begin{array}{l}5-9 \\
5\end{array}$ \\
\hline $\begin{array}{l}\text { \% stained quartz } \\
\text { in total quartz }(125-250 \mu \mathrm{m})\end{array}$ & $\begin{array}{l}3-10 \\
\text { (generally low, } \\
\text { depends on source) }\end{array}$ & $2-27$ & $14-68$ & $10-17$ \\
\hline$(250-500 \mu \mathrm{m})$ & - & (Site 135: 28-31) & $14-77$ & $? 15$ \\
\hline $\begin{array}{l}\text { \% frosted quartz } \\
\text { in total quartz }(125-250 \mu \mathrm{m}) \\
\qquad(250-500 \mu \mathrm{m})\end{array}$ & $0-9$ & $\begin{array}{l}- \\
-\end{array}$ & $\begin{array}{l}10-15 \\
12-43\end{array}$ & $\begin{array}{l}13-19 \\
? 15\end{array}$ \\
\hline$\%$ fecal pellets $(125-250 \mu \mathrm{m})$ & $0-0,8$ & $\begin{array}{l}8-50 \\
\text { (Predominantly con- } \\
\text { sisting of silty muds) }\end{array}$ & - & - \\
\hline$\%$ plant fibers $(250-500 \mu \mathrm{m})$ & $0-0,25$ & $0,5-5,0$ & - & - \\
\hline Shallow-water fossils & Very rare & $\begin{array}{l}\text { Pro-delta faunal comm: } \\
\text { thin-shelled mollusks, } \\
\text { ostracodes, benthonic } \\
\text { foraminifera, echinoids }\end{array}$ & $\begin{array}{l}\text { Hard-bottom faun } \\
\text { and inner shelf: } p \\
\text { large and small for }\end{array}$ & $\begin{array}{l}\text { a from beach } \\
\text { elecypods, barnacles, } \\
\text { raminifera }\end{array}$ \\
\hline $\begin{array}{l}\text { Shallow-water nonbiogenous } \\
\text { grains }\end{array}$ & $\begin{array}{l}\text { Oöids, rounded } \\
\text { Debris }\end{array}$ & $\begin{array}{l}\text { Semilithified deltaic } \\
\text { silty mud clasts; limo- } \\
\text { nitic siltite; glauconite } \\
\text { pellets }\end{array}$ & $\begin{array}{l}\text { Superficial oöids, } \\
\text { sandstone debris }\end{array}$ & beachrock, limonite- \\
\hline $\begin{array}{l}\text { Preservation of carbonate } \\
\text { grains }\end{array}$ & Bad & Optimal & Medium to bad & Medium to bad \\
\hline Other criteria & Little mica & Mica is common & Almost no mica & Almost no mica \\
\hline
\end{tabular}

Sahara-desert belt back into the Tertiary. The zone includes the Pliocene sands of Cores 367-3 through 5, which occur on the outside farther south because of diverting channel directions on the continental rise.

The sand layers of all remaining cores and epochs are identified as of mainly fluvial origin.

Turbiaites and contourites appear to be concentrated only in certain horizons: in the early Oligocene, the earliest Miocene, the middle to late Miocene boundary, and the late Pliocene and Pleistocene. This seems to hold true for all sites except for 370 , even when the shortage of core recovery is considered. The persistent turbidites of Site 370 are probably the result of a special hinterland situation with the rising High Atlas Mountains.

The distribution of turbidites (Figure 11) appears significant with respect to the above model. The turbidites south of $20^{\circ} \mathrm{N}$ are interpreted as a repeated coincidence of low sea level, strong off-shore Trade Winds moving dunes to the shoreline, and a general southward thrust of the Paleo-Sahara, such as during the glacials. Such short-term climatic events would date at approximately 23 to 20,13 to 12 , and 3 to 2 , and perhaps also at 38 to ?34 m.y.B.P. The composition of the Pleistocene turbidites (fluvial sand) from Cores 367. 1 and 2 characterizes the source area as a synglacial environment along a desert margin analogous to the modern Senegal River mouth.

The hypothesis of several drastic climatic deteriorations in the Neogene is supported by details of the sandlayer composition. The high proportion of glauconite particles in most turbidites can be related to intensive erosion of older shelf sediments, which occurred best during periods of low sea level and exposed shelves. Further, laminated coarse siltites are a common component of pelagic sediment debris. They are interpreted as erosional remains of typical wind-dust beds at the continental margin and point to a contemporaneous or slightly earlier period of dust storms. In addition, siliceous fossils and fish remains are the dominant biogenous component in both early Miocene and early Oligocene contourites and eolian-sand 
turbidites. These might indicate an increased coastal upwelling activity related to the increased off-land winds, using the analogy with Pleistocene glacials (Diester-Haass, 1976). These results agree well with data from Schrader and Diester-Haass (this volume) from Site 369. The concept of increased upwelling causing cool temperatures along the continental margin also agrees with the composition of the reworked shallow-water fossils. This group represents a temperate-latitude association of the "foramol" type (Lees, 1975), which is analogous to those of the modern environment off West Africa which is influenced by upwelling. Finally, the early Miocene contourites of Site 368 mark a period of increased bottom-current activity. They may have originated from vigorous intrusions of Antarctic Bottom Water such as were common during Pleistocene climatic deteriorations (Gardner, 1975).

The proposed arid, cool-temperature, low sea level phases cannot be very well substantiated by evidence from land geology. Deserts, in general, and especially such short-time glacial-climatic events, can rarely be dated geologically (average duration of Pleistocene glacial stages 10 to 20 thousand years). Further, regressions result in erosion and leave behind few traces, mainly hiatuses. Most of the late Neogene was formed as "continental terminal" devoid of any features amenable to precise dating or records of environmental history. Nevertheless, extensive unconformities and associated phases of sea-level lowering were reported from several parts of northwest Africa (Ratschiller, 1970; Dillon and Sougy, 1974; Lietz and Schmincke, 1975). These unconformities date at 27 to $20,6.5$ and 2.5 , possibly also at 40 to 38 m.y.B.P. which correlate with the ages derıved from the results of this study.

Neogene desert sandstones are rarely encountered. One such deposit is the upper Miocene of Southern Morocco in the El Aaiun Basin, in a northerly "interglacial" position (Ratschiller, 1970).

Finally, east-west barriers against the north-south mixing of mammalians (e.g., antilopes) have been noted in North Africa by paleontologists, especially before 20 m.y.B.P., and possibly at 10 and 6 m.y.B.P. (Charles Smart, personal communication). These barriers may have been the proposed Paleo-Sahara belts.

Widespread evidence of the proposed Neogene events can be found in the marine record if one accepts a global control of climatic changes. Berger and Winterer (1974) and van Andel (1975) report two main fluctuations of the carbonate compensation depth (CCD) taking place at approximately 27 to 20 and 13 m.y.B.P. occurring simultaneously in the different ocean basins. Similarly, Schlanger and Douglas (1974) note well-documented seismic reflectors in large parts of the equatorial Pacific Basin which are related to the degree of carbonate cementation, and are dated in various DSDP cores as 26 to 21,14 to 12,6 to 5 , and 3 m.y.B.P. old. They tentatively correlate the horizons with major glacio-eustatic phases of the growing Antarctic and Arctic glaciations. This seems to be rather confirmed by recent oxygen-isotope curves from southern Pacific DSDP sites (Shackleton and Kennett,
1974). They show three phases of surface-water temperature minima dated as Oligocene to lower early Miocene, early late Miocene, and middle Pliocene. The events are also correlated with ice-cap formation on Antarctica using estimates of bottom water temperatures. Bottom waters are thought to be responsible for the generation of cold Antarctic Bottom Water intruding the mid Atlantic. Summarizing the late Neogene climatic events, Berggren and van Couvering (1974) emphasize the significance of a cooling phase at 3.0 m.y.B.P., when the first ice-rafted sediments appeared in the North Atlantic. Figure 11 shows no turbidites in response to the worldwide "Messinian event" of 6 to 5 m.y.B.P. (Ryan et al., 1974). This is possibly due to an unusually spotty core coverage in this short stratigraphic section.

Still, many of these correlations might be rather hypothetical and incidental, even though they show a number of impressive agreements. The findings on a paleo-Sahara belt during stages of low sea level, increased off-shore Trade Winds, and upwelling add new inputs to discussions of Neogene climatic history. However, a full judgment of the evidence and interpretations in this paper is only meaningful when included with the related results from the continuous pelagic sections of Sites 366 and 369 (Diester-Haass, this volume).

\section{ACKNOWLEDGMENTS}

This investigation was supported by stimulating discussions and suggestions by a great number of people. I am particularly grateful to E. Seibold, Kiel, to many members of the CLIMAP group at the Lamont-Doherty Geological Observatory, and to L. Diester-Haass, Kiel. Sincere thanks are extended to E. Walger and M. Barton, who critically reviewed the manuscript. The author received valuable technical assistance from M.R. de Voe, J. Mienert, A. Scholtis, and B. Salomon.

Much of this work was carried out during a one-year visit at the hospitable Lamont-Doherty Geological Observatory, N.Y., under the generous funding of the Deutsche Forschungsgemeinschaft (Grant Sa 207/4). Finally, I wish to acknowledge the shipboard party for making Leg 41 samples available for this shore-lab study.

\section{REFERENCES}

Bagnold, A., 1941. The physics of blown sand and desert dunes: New York (Methuen and Co.), p. 265.

Berger, W.H. and von Rad, U., 1972. 26. Cretaceous and Cenozoic sediments from the Atlantic Ocean. In Hayes, D.E., Pimm, A.C., et al., Initial Reports of the Deep Sea Drilling Project, Volume 14: Washington (U.S. Government Printing Office), p. 787-954.

Berger, W.H. and Winterer, E.L., 1974. Plate stratigraphy and fluctuating carbonate line. In Hsü, K.J. and Jenkyns, H.C. (Eds.), Pelagic sediments on land and under sea: Intl. Assoc. Sedimentol. Spec. Publ. 1, p. 11-48.

Berggren, W.A. and van Couvering, J.A., 1974. The late Neogene: Dev. Palaeont. Strat. 2: New York (Elsevier).

Birch, G.F., 1973. Phosphorite deposits off the southwestern Cape coast and their relationship to the unconsolidated sediment: Prog. Rept. 1973, S. African Nat. Comm. Ocean. Res. Mar. Geol. Progr. Univ. of Cape Town, Dept. of Geol., v. 6, p. 16-23. 
Bouma, A.H., 1962. Sedimentology of some flysch deposits. A graphic approach to facies interpretation: New York (Elsevier), p. 168.

Bouma, A.H. and Hollister, C.D., 1973. Deep ocean basin sedimentation: SEPM Pacific Sect. Short Course, Turbidites and deep-water sedimentation, p. 79-118.

Carter, R.M., 1975. A discussion and classification of subaquaeous mass-transport with particular application to grain-flow, slurry-flow, and fluxoturbidites: Earth-Sci. Rev., v. 11, p. 145-178.

Diester-Haass, L., 1975. Late Quaternary sedimentation and climate in the East Atlantic between Senegal and Cape Verde Islands: "Meteor" Forsch.-Ergebn. C, v. 20, p. 132 .

1976. Sediments as indicators of upwelling: III. Int. Symp. Upwelling Ecosystems Kiel, Proc.: Heidelberg (Springer-Verlag).

Dillon, W.P. and Sougy, J.M.A., 1974. Geology of West Africa and Canary and Cape Verde Islands. In Nairn, A.E.M. and Stehli, F.G. (Eds.), The ocean basins and margins, The North Atlantic: New York (Plenum Press), v. 2, p. 315-390.

Elouard, P., Faure, H., and Hebrard, L., 1969. Quaternaire du littoral Mauretanien entre Nouakchott et Port-Etienne: Assoc. Sénég. Quatern. Ouest-Afr. Bull., v. 23, p. 15-24.

Ericson, D.B., Ewing, M., Wollin, G., and Heezen, B.C., 1961. Atlantic deep-sea sediment cores: Geol. Soc. Am. Bull., v. 72, p. 193-286.

Fairbridge, R.W., 1947. Coarse sediments on the edge of continental shelf: Am. J. Sci., v. 245, p. 146-153.

1965. Eiszeitklima in Nordafrika: Geol. Rdsch., v. 54 , p. $399-414$.

Franchetau, J., 1970. Paleomagnetism and plate tectonics: SIO Reference 70-30, p. 345.

Fritz, St.J. and Pilkey, O.H., 1975. Distinguishing bottom and turbidity current coarse layers on the continental rise: J. Sediment. Petrol., v. 45, p. 57-62.

Gardner, J.V., 1975. Late Pleistocene carbonate dissolution cycles in the eastern equatorial Atlantic. In Sliter, W., Bé, A.W.H., and Berger, W. (Eds.), Dissolution of Deep-Sea Carbonates: Cushman Found. Foram. Res., Spec. Publ. 13, p. 129-141.

Hayes, D., Pimm, A.C., et al., 1972. Initial Reports of the Deep Sea Drilling Project, Volume 14: Washington (U.S. Government Printing Office).

Hebrard, L., Faure, H., and Elouard, P., 1969. Age absolu du volcanisme quaternaire de Dakar (Sénégal): Assoc. Sénég. Quatern. Ouest-Afr. Bull., v. 22, p. 15-19.

Hjulström, F., 1939/1955. Transportation of detritus by moving water. In Trask, P.D. (Ed.), Recent marine sediments: Am. Assoc. Petrol. Geol. Symp., p. 5-31.

Hollister, C.D. and Heezen, B.C., 1972. Geologic effects of ocean-bottom currents: western North Atlantic. In Gordon and Breach (Eds.), Studies in physical oceanography: v. 2, p. 37-66.

Koopmann, B., Lees, A., Piessens, P., and Sarnthein, M., in preparation. Recent silty marls and skeletal sands of the Baie du Lévrier, Mauritania.

Lange, H. and Sarnthein, M., 1970. Glaukonitkörner in rezenten Sedimenten des Persischen Golfs: Geol. Rdsch., v. 60 , p. $256-264$.

Lees, A., 1975. Possible influence of salinity and temperature on modern shelf carbonate sedimentation: Mar. Geol., v. 19 , p. $159-198$.
Lietz, J. and Schmincke, H.U., 1975. Miocene-Pliocene sea level changes and volcanic phases on Gran Canaria (Canary Islands) in the light of new K-Ar ages: Paleogeography, v. 18 , p. 213-239.

Parkin, D.W., 1974. Trade-wind during the glacial cycles: Roy. Soc. London Proc., Ser. A, v. 337, p. 73-100.

Radczewski, O., 1939. Eolian deposits in marine sediments. In Trask, P.D. (Ed.), Recent marine sediments: Am. Assoc. Petrol. Geol. Symp., p. 496-502.

Ratschiller, L.K., 1970. Lithostratigraphy of the Northern Spanish Sahara: Mem. Museo Tridentino Sci. Nat., v. 18, p. $9-84$

Ryan, W.B.F., Cita, M.B., Dreyfus-Rawson, M., Burckle, L.H., and Saito, T., 1974. A paleomagnetic assignment of Neogene stage boundaries and the development of isochronous datum planes between the Mediterranean, the Pacific and Indian Oceans in order to investigate the response of the world ocean to the Mediterranean "salinity crisis": Riv. Ital. Paleontol., v. 80, p. 631-688.

Sarnthein, M., 1971. Oberflächensedimente im Persischen Golf und Golf von Oman. II. Quantitative Komponentenanalyse der Grobfraktion: "Meteor" Forsch.Ergebn. C, v. 5, p. 1-113.

Sarnthein, M. and Diester-Haass, L., in press. Eolian-sand turbidites: J. Sediment. Petrol.

Sarnthein, M. and Walger, E., 1973. Classification of modern marl sediments in the Persian Gulf by factor analysis. In Purser, B. (Ed.), Persian Gulf symposium: New York (Springer-Verlag), p. 81-98.

1974. Der äolische Sandstrom aus der W-Sahara zur Atlantikküste: Geol. Rdsch., v. 63, p. 1065-1087.

Schlanger, S.O. and Douglas, R.G., 1974. The pelagic oozechalk-limestone transition and its implications for marine stratigraphy: Int. Assoc. Sediment. Spec. Publ., v. 1, p. 117-148.

Schwarz, H.-U., Einsele, G., and Herm, D., 1975. Quartzsandy, grazing contoured stromatolites from coastal embayments of Mauritania, West Africa: Sedimentology, v. 22 , p. $539-562$.

Shackleton, N.J. and Kennett, J.P., 1974. Paleotemperature history of the Cenozoic and the initiation of Antarctic glaciation: Oxygen and carbon isotope analysis in DSDP Sites 277, 279, and 281. In Kennett, J.P., Houtz, R.E., et al., Initial Reports of the Deep Sea Drilling Project, Volume 29: Washington (U.S. Government Printing Office), p. 743-755.

Van Andel, T., 1975. Mesocoic/Cenocoic calcite compensation depth and the global distribution of calcareous sediments: Earth Planet. Sci. Lett., v. 26, p. 187-194.

\section{APPENDIX A \\ Summary of Coarse Fraction Analysis (detailed explanation see also text)}

Note: biog., biogenous; comp., component; qu., quartz; sed., sediment; w., water;

$\mathrm{A}$, arenaceous foraminifera; B, barnacles; $\mathrm{Br}$, bryozoans; $\mathrm{D}$, decapoda; Dt, diatoms; E, echinoids; F, benthonic foraminifera; $\mathrm{Fi}$, fish debris; G, gastropods; O, ostracodes; P, pelecypods; Pl, planktonic foraminifera; R, radiolarians; S, sponges;

cont., contourite; e.t., eolian-sand turbidite; f.t., fluvial-sand turbidite. Changes of grain-size fraction of data as indicated in columns. 



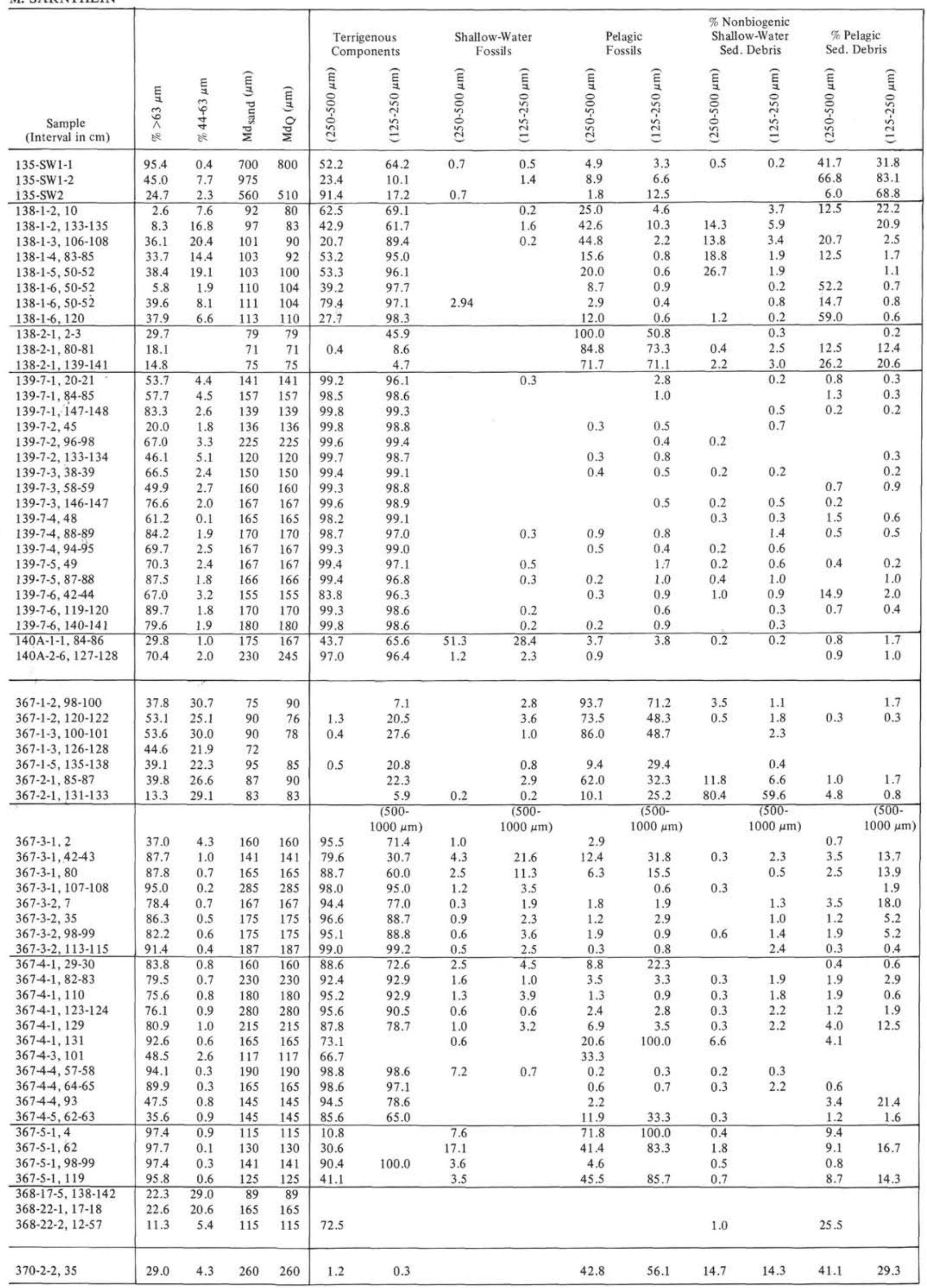




\begin{tabular}{|c|c|c|c|c|c|c|c|c|c|c|c|c|}
\hline \multicolumn{2}{|c|}{$\begin{array}{l}\% \text { Fecal } \\
\text { Pellets }\end{array}$} & \multicolumn{2}{|c|}{ \% Feldspar } & \multicolumn{2}{|c|}{$\begin{array}{l}\text { \% Stained } \\
\text { Quartz }\end{array}$} & \multicolumn{2}{|c|}{$\begin{array}{l}\% \text { Frosted } \\
\text { Quartz }\end{array}$} & \multicolumn{2}{|c|}{$\begin{array}{c}\text { Quartz + Feldsp. } \\
\text { Mica }\end{array}$} & \multirow{2}{*}{ 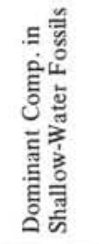 } & \multirow{2}{*}{ 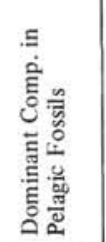 } & \multirow{2}{*}{ 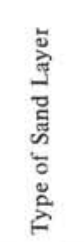 } \\
\hline 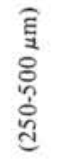 & 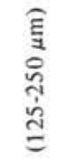 & 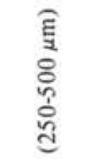 & 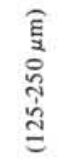 & 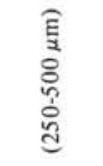 & 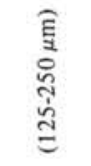 & 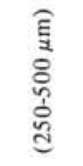 & 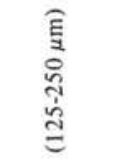 & 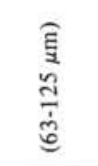 & 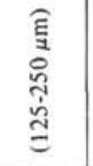 & & & \\
\hline & & 23.3 & 35.6 & 31.6 & 19.1 & 7.2 & 1.8 & & & $\mathrm{E} / \mathrm{P} /$ & $\mathrm{Pl} / \mathrm{G} / \mathrm{F}$ & f.t. \\
\hline 0.6 & 0.3 & 25.5 & 30.0 & 31.4 & 17.0 & 8.6 & & & & $-1-1$ & $\mathrm{Pl} / \mathrm{F} / \mathrm{R}$ & f.t. \\
\hline & & 16.6 & 25.0 & 28.1 & 27.8 & 6.3 & & & & $\mathrm{P} / \mathrm{F} / \mathrm{G}$ & $\mathrm{Pl} / \mathrm{F} / \mathrm{R}$ & f.t. \\
\hline & 0.4 & & 15.9 & & 7.4 & & 9.5 & 8 & 17 & $-1-1-$ & $\mathrm{Fi} / \mathrm{Dt} /$ & cont. \\
\hline & 0.8 & & 11.8 & & 9.4 & & 6.6 & 72 & 22 & P/ & $\mathrm{Fi} / \mathrm{F} / \mathrm{P}$ & cont. \\
\hline & 0.3 & 17.3 & 12.7 & $(50.0)$ & 10.7 & & 14.9 & & 142 & $\mathrm{P} / \mathrm{G} / \mathrm{F}$ & $\mathrm{Fi} / \mathrm{P} / \mathrm{PI}$ & e.t. \\
\hline & & & 12.5 & $(25.0)$ & 12.4 & (16.7) & 14.1 & 434 & 113 & & $\mathrm{Fi} / \mathrm{P} / \mathrm{O}$ & e.t. \\
\hline & & & 12.1 & $(14.3)$ & 13.5 & (28.5) & 19.4 & & 445 & & $\mathrm{R} / \mathrm{O} / \mathrm{Fi}$ & e.t. \\
\hline & & & 10.0 & $(28.5)$ & 11.2 & (43.0) & 15.4 & 153 & 210 & & $\mathrm{R} / \mathrm{F} / \mathrm{E}$ & e.t. \\
\hline & & & 16.2 & $(4.8)$ & 15.5 & (14.3) & 12.8 & & 493 & $\mathrm{P} /$ & $\mathrm{Fi} / \mathrm{R} / \mathrm{P}$ & e.t. \\
\hline 1.2 & & & 9.9 & $(10.0)$ & 17.0 & (15.0) & 16.1 & & & $\mathrm{P} /$ & $\mathrm{F} / \mathrm{R} / \mathrm{S}$ & e.t. \\
\hline & & & 9.5 & & 10.4 & & 4.1 & 450 & & & $\mathrm{R} / \mathrm{S} / \mathrm{Fi}$ & cont. \\
\hline 1.2 & 0.8 & & 25.7 & & 3.7 & & 7.4 & & 28 & & $\mathrm{R} / \mathrm{S} / \mathrm{Fi}$ & cont. \\
\hline & 0.3 & & 11.8 & & 4.6 & & 0.0 & 282 & 11.5 & & $\mathrm{R} / \mathrm{Fi} / \mathrm{S}$ & cont. \\
\hline & & 14.9 & 10.5 & 15.7 & 7.8 & 14.8 & 9.8 & 486 & & $\mathrm{~F} / \mathrm{P} /$ & $\mathrm{Dt} / \mathrm{F} / \mathrm{R}$ & e.t. \\
\hline 0.2 & & 17.9 & 10.4 & 15.5 & 11.9 & 12.1 & 17.4 & 628 & 270 & & $\mathrm{Dt} / \mathrm{R} / \mathrm{S}$ & e.t. \\
\hline & & 17.1 & 18.5 & 19.5 & 10.3 & 17.4 & 14.3 & 235 & & & $\mathrm{P} / \mathrm{Dt} / \mathrm{R}$ & e.t. \\
\hline & & 9.5 & 12.3 & 18.6 & 14.3 & 21.4 & 14.9 & & & & $\mathrm{~F} /$ & e.t. \\
\hline 0.2 & 0.2 & 17.4 & 13.1 & 21.1 & 13.5 & 27.6 & 14.6 & & & & $\mathrm{D} t / \mathrm{R} / \mathrm{Fi}$ & e.t. \\
\hline & & 11.0 & 14.0 & 20.5 & 18.2 & 24.9 & 12.0 & & & & $\mathrm{Dt} / \mathrm{Fi} / \mathrm{P}$ & e.t. \\
\hline & & 17.2 & 14.5 & 20.7 & 13.2 & 19.3 & 11.5 & & & & $\mathrm{Dt} / \mathrm{R} / \mathrm{Fi}$ & e.t. \\
\hline & & 10.0 & 11.4 & 24.1 & 23.9 & 19.7 & 11.4 & & & & $\mathrm{R} / \mathrm{Dt} /$ & e.t. \\
\hline & & 20.8 & 16.2 & 24.7 & 12.4 & 19.2 & 20.7 & & & & $\mathrm{R} / \mathrm{P} / \mathrm{Fi}$ & e.t. \\
\hline & & 14.0 & 12.9 & 21.0 & 18.2 & 28.8 & 12.5 & & & & $\mathrm{R} /$ & e.t. \\
\hline & & 17.3 & 10.7 & 23.2 & 12.1 & 20.5 & 16.7 & & & $\mathrm{P} / \mathrm{F} /$ & $\mathrm{Dt} / \mathrm{P} / \mathrm{F}$ & e.t. \\
\hline & & 21.3 & 13.7 & 15.5 & 13.2 & 14.8 & 13.0 & & & F/ & $\mathrm{R} / \mathrm{Dt} / \mathrm{Pl}$ & e.t. \\
\hline & & 22.0 & 15.3 & 14.5 & 9.1 & 15.7 & 11.9 & & & $\mathrm{~F} / \mathrm{P} / \mathrm{D}$ & $\mathrm{R} / \mathrm{Dt} / \mathrm{F}$ & e.t. \\
\hline & & 21.1 & 16.6 & 20.3 & 7.7 & 13.2 & 7.7 & & & $\mathrm{~F} / \mathrm{Pl} /$ & $\mathrm{R} / \mathrm{F} / \mathrm{Dt}$ & e.t. \\
\hline & & 22.8 & 18.7 & 20.5 & 19.4 & 14.5 & 9.9 & & & & $\mathrm{R} / \mathrm{Dt} / \mathrm{F}$ & e.t. \\
\hline & & 22.4 & 15.7 & 19.5 & 8.9 & 13.4 & 9.1 & & 638 & $\mathrm{~F} /$ & $\mathrm{Dt} / \mathrm{F} / \mathrm{D}$ & e.t. \\
\hline & & & 15.6 & 16.5 & 9.0 & 11.9 & 12.2 & 434 & 572 & $\mathrm{~F} /$ & $\mathrm{R} / \mathrm{Dt} / \mathrm{F}$ & e.t. \\
\hline & & & & 22.5 & 19.1 & 23.5 & 16.1 & 208 & & $\mathrm{P} / \mathrm{B} / \mathrm{E}$ & $\mathrm{F} / \mathrm{Pl} / \mathrm{B}$ & e.t. \\
\hline & & & & $\begin{array}{c}17.1 \\
(63-125\end{array}$ & 10.4 & 24.5 & 19.9 & 325 & & $\mathrm{P} / \mathrm{F} / \mathrm{L}$ & $\mathrm{R} /$ & e.t. \\
\hline & & & & $\mu \mathrm{m})$ & & & & & & & & \\
\hline 2.8 & 16.1 & & & 33.5 & 20.0 & & & 66 & 7 & $\mathrm{P} / \mathrm{F} /$ & $\mathrm{F} / \mathrm{Pl} / \mathrm{O}$ & f.t. \\
\hline 24.9 & 25.4 & & & 30.0 & 27.0 & & & 50 & 19.5 & $\mathrm{P} / \mathrm{F} / \mathrm{D}$ & $\mathrm{PI} / \mathrm{F} / \mathrm{P}$ & f.t. \\
\hline 13.6 & 19.8 & & & 30.8 & 26.0 & & & 83 & 26 & $\mathrm{P} / \mathrm{F} /$ & $\mathrm{F} / \mathrm{Pl} / \mathrm{P}$ & f.t. \\
\hline 90,1 & 48.6 & & & 33.5 & 8.0 & & & 75 & 20 & $\mathrm{P} /$ & $\mathrm{Pl} / \mathrm{F} / \mathrm{Fi}$ & f.t. \\
\hline 25.2 & 33.5 & & & 23.0 & 20.0 & & & 74 & 22 & $\mathrm{P} / \mathrm{F} /$ & $\mathrm{Pl} / \mathrm{F} / \mathrm{O}$ & f.t. \\
\hline 4.6 & 8.1 & & & 23.0 & 13.3 & & & 54 & 6 & $\mathrm{P} /$ & $\mathrm{Pl} / \mathrm{F} / \mathrm{S}$ & f.t. \\
\hline & & & $\begin{array}{l}(500- \\
1000)\end{array}$ & $\begin{array}{l}(250- \\
500)\end{array}$ & $\begin{array}{l}(500- \\
1000)\end{array}$ & & $\begin{array}{c}(500- \\
1000 \mu \mathrm{m})\end{array}$ & & & & & \\
\hline & & 31.7 & 25.0 & 68.5 & 66.6 & 31.1 & 33.3 & 9000 & & $\mathrm{~F} / \mathrm{P} /$ & $\mathrm{F} / \mathrm{Pl} / \mathrm{G}$ & e.t. \\
\hline & & 35.5 & 12.0 & 63.9 & 72.6 & 19.1 & 18.2 & & & $\mathrm{P} / \mathrm{F} / \mathrm{B}$ & $\mathrm{Pl} / \mathrm{F} / \mathrm{E}$ & e.t. \\
\hline & & 38.8 & 30.7 & 65.2 & 82.3 & 13.0 & 19.0 & & & $\mathrm{P} / \mathrm{F} / \mathrm{B}$ & $\mathrm{PI} / \mathrm{F} /$ & e.t. \\
\hline & & 31.5 & 19.5 & 62.0 & 82.0 & 28.4 & 28.7 & 6500 & & $\mathrm{~F} / \mathrm{B} / \mathrm{P}$ & $\mathrm{Pl} / \mathrm{F} / \mathrm{E}$ & e.t. \\
\hline & & 26.5 & 19.5 & 65.5 & 84.1 & 26.4 & 42.8 & & & $\mathrm{~B} / \mathrm{P} /$ & $\mathrm{Pl} / \mathrm{F} / \mathrm{Fi}$ & e.t. \\
\hline & & 25.0 & 18.3 & 64.6 & 77.3 & 34.2 & 47.8 & 16200 & & $\mathrm{P} / \mathrm{G} /$ & $\mathrm{F} / \mathrm{Pl} / \mathrm{P}$ & e.t. \\
\hline & & 34.1 & 24.2 & 66.6 & 69.8 & 32.4 & 48.0 & & & $\mathrm{P} / \mathrm{F} / \mathrm{B}$ & $\mathrm{Pl} / \mathrm{F} /$ & e.t. \\
\hline & & 26.3 & 22.2 & 61.5 & 76.0 & 26.3 & 43.4 & 4400 & & $\mathrm{~F} / \mathrm{P} / \mathrm{B}$ & $\mathrm{Pl} / \mathrm{Fi} / \mathrm{F}$ & e.t. \\
\hline & & 27.0 & 12.3 & 53.6 & 75.0 & 42.9 & 68.0 & 9300 & 5200 & $\mathrm{~F} / \mathrm{P} / \mathrm{B}$ & $\mathrm{Pl} / \mathrm{F} / \mathrm{A}$ & e.t. \\
\hline & & 28.5 & 10.1 & 65.8 & 81.0 & 37.5 & 56.8 & 10000 & 4900 & $\mathrm{P} / \mathrm{B} / \mathrm{F}$ & $\mathrm{F} / \mathrm{Pl} / \mathrm{P}$ & e.t. \\
\hline & & 20.3 & 12.5 & 69.5 & 82.3 & 38.9 & 55.5 & & & $\mathrm{~F} / \mathrm{B} / \mathrm{P}$ & $\mathrm{Pl} / \mathrm{F} /$ & e.t. \\
\hline & & 24.8 & 9.7 & 63.2 & 76.4 & 41.2 & 48.3 & & & $\mathrm{G} / \mathrm{B} / \mathrm{P}$ & $\mathrm{Pl} / \mathrm{F} /$ & e.t. \\
\hline & & 25.1 & 11.0 & 70.0 & 80.0 & 25.5 & 58.0 & & & $\mathrm{~B} / \mathrm{Br} / \mathrm{F}$ & $\mathrm{Pl} / \mathrm{F} / \mathrm{A}$ & e.t. \\
\hline 0.2 & & 28.1 & & 53.7 & & 24.2 & & & & $\mathrm{P} / \mathrm{E} / \mathrm{s}$ & $\mathrm{Pl} / \mathrm{F} / \mathrm{P}$ & e.t. \\
\hline & & 33.3 & & 50.0 & & & & & & & $\mathrm{Pl} /$ & cont.? \\
\hline & & 25.6 & 19.7 & 75.8 & 84.0 & 24.2 & 44.0 & & & $\mathrm{~F} / \mathrm{P} /$ & $\mathrm{Pl} / \mathrm{F} /$ & e.t. \\
\hline & & 29.7 & 14.4 & 67.3 & 87.1 & 40.9 & 52.2 & 8000 & & & $\mathrm{Pl} / \mathrm{F} /$ & e.t. \\
\hline & & 17.6 & 18.2 & 52.5 & 87.6 & 24.1 & 67.6 & & & & $\mathrm{Pl} / \mathrm{A} /$ & e.t. \\
\hline & & 20.9 & 43.3 & 76.9 & 100.0 & 31.0 & 76.6 & 3000 & & & $\mathrm{Pl} / \mathrm{F} /$ & e.t. \\
\hline & & 10.0 & & 68.9 & & 42.2 & & & 3800 & $\mathrm{P} / \mathrm{Br} / \mathrm{E}$ & $\mathrm{Pl} / \mathrm{P} / \mathrm{F}$ & e.t. \\
\hline & & 20.1 & & 56.5 & & 14.8 & & & & $\mathrm{P} / \mathrm{Br} / \mathrm{F}$ & $\mathrm{P} / \mathrm{Pl} / \mathrm{F}$ & e.t. \\
\hline & & 20.8 & & 63.1 & 100.0 & 24.1 & 100.0 & & & $\mathrm{P} / \mathrm{F} / \mathrm{D}$ & $\mathrm{P} / \mathrm{F} / \mathrm{Pl}$ & e.t. \\
\hline & & 32.2 & & 70.0 & & 18.3 & & & 6200 & $\mathrm{P} / \mathrm{G} / \mathrm{B}$ & $\mathrm{Pl} / \mathrm{P} / \mathrm{F}$ & e.t. \\
\hline & & & & & & & & 9000 & 50 & & $\mathrm{Fi} /$ & cont. \\
\hline & & $\begin{array}{c}16.0 \\
(63-125 \\
\end{array}$ & & $\begin{array}{c}3.8 \\
(63-125\end{array}$ & & 19.0 & & & & & $\mathrm{Fi} /$ & $\begin{array}{l}\text { cont. } \\
\text { cont. }\end{array}$ \\
\hline & & $\mu \mathrm{m})$ & & $\mu \mathrm{m})$ & & & & & & & & \\
\hline 0.5 & & 1.9 & & 22.0 & & & & 106 & 1 & G/ & $\mathrm{Pl} / \mathrm{F} / \mathrm{A}$ & f.t. \\
\hline
\end{tabular}

